\title{
Feeding ecology of myctophid fishes in the northern Scotia Sea
}

\author{
R. S. Shreeve ${ }^{1}$, M. A. Collins ${ }^{1,2, *}$, G. A. Tarling ${ }^{1}$, C. E. Main $^{1,3}{ }^{3}$ P. Ward ${ }^{1}$, N. M. Johnston ${ }^{1}$ \\ ${ }^{1}$ British Antarctic Survey, Natural Environment Research Council, High Cross, Madingley Road, Cambridge CB3 0ET, UK \\ ${ }^{2}$ Present address: Government of South Georgia and South Sandwich Islands, Government House, Stanley, Falkland Islands \\ ${ }^{3}$ Present address: Fisheries Research Services, 375 Victoria Road, Aberdeen AB11 9DB, UK
}

\begin{abstract}
The diets of 9 species of myctophid fishes, Electrona carlsbergi, E. antarctica, Gymnoscopelus fraseri, G. nicholsi, G. braueri, Protomyctophum bolini, P. choriodon, Krefftichthys anderssoni and Nannobrachium achirus, were investigated during austral autumn in the northern Scotia Sea. Based on the percent index of relative importance (\%IRI), the data suggest dietary specialisation in some species, which may permit resource partitioning. Hierarchical agglomerative cluster analysis of Bray-Curtis similarity ( $60 \%$ threshold) separated the myctophid community into distinct feeding guilds. One group (G. braueri and E. antarctica) fed principally on Themisto gaudichaudii, another (P. choriodon and G. fraseri) primarily on copepods (Metridia spp. and Rhincalanus gigas), and a third group (G. nicholsi and P. bolini) consumed copepods and euphausids (mostly Metridia spp. and Euphausia frigida). The diets of E. carlsbergi and $K$. anderssoni differed from the other species, with E. carlsbergi being the only species that consumed salps. There was a general switch in diet from copepods to euphausiids and amphipods as the myctophid predator size increased. Dietary specialisation is likely the result of a combination of predator size, gape size, filtering capacity of the gill rakers and the vertical distribution of predators and prey. Antarctic krill were only consumed by the larger myctophids, which represented a numerically minor part of the myctophid community, supporting the concept that myctophids can provide a krill-independent link between secondary production and higher trophic levels. However, the northern Scotia Sea is dominated by adult krill, which are only suitable as prey for larger fish. In the northern Scotia Sea, myctophid predation had a very small impact on copepod production but a higher impact on macrozooplankton, with a best-estimate of $4 \%$ of the daily production of Themisto gaudichaudii and $6 \%$ of that of Euphausia superba being consumed.
\end{abstract}

KEY WORDS: Southern Ocean $\cdot$ Diet $\cdot$ Predation mortality $\cdot$ Copepods $\cdot$ Euphausiid $\cdot$ Predator $\cdot$ Prey Resale or republication not permitted without written consent of the publisher

\section{INTRODUCTION}

Lantern fish or myctophids (Family Myctophidae) are the dominant mesopelagic fish in most of the world's oceans, playing a key role in oceanic foodwebs (Gjøsaeter \& Kawaguchi 1980, Mann 1984, Hopkins \& Gartner 1992, Tsarin 1997) and, through their extensive vertical migrations, contributing to the export of carbon from the surface to mesopelagic depths. Myctophids consume herbivorous and omnivorous zooplankton (e.g. copepods \& amphipods) (Pakhomov et al. 1996, Williams et al. 2001, Pusch et al. 2004) and are in turn consumed by a range of oceanic top predators (Tsarin 1997, Olsson \& North 1997, Cherel et al. 2002), thus providing a key link in the open ocean food web. Consequently, determining the trophic ecology of abundant myctophid species is essential in understanding the operation of ocean ecosystems.

Whilst the food web of the Southern Ocean is often perceived to be dominated by Antarctic krill Euphausia superba, it is clear that other trophic pathways are both regionally and seasonally important, with myctophids providing a key alternative (Hempel 1985, Murphy et al. 2007). Furthermore, with evidence of a 
long-term decline in krill (Atkinson et al. 2004), the importance of these krill-independent pathways is likely to increase. The Southern Ocean myctophid fauna includes approximately 35 species in 12 genera (Hulley 1990), with an estimated biomass of between 70 and 200 million tonnes (Mt) (Lubimova et al. 1987). In the Southern Ocean, myctophids are the primary prey of several important species such as king penguins (Olsson \& North 1997), elephant seals (Cherel et al. 2008) and the squid Martialia hyadesi (Rodhouse et al. 1992), and are regionally and seasonally important to many other predators, such as fur seals (Guinet et al. 2001, Reid et al. 2006). Despite their abundance and ecological significance, data on the ecology of myctophids are remarkably sparse, globally and particularly in the Southern Ocean.

Determining diet is essential to understanding food web dynamics and resource partitioning (Ross 1986), but studies of Southern Ocean myctophid diets have, so far, been restricted to the most abundant species on limited spatial and temporal scales, in some cases with very small sample sizes (Rowedder 1979, Naumov et al. 1981, Kozlov \& Tarverdiyeva 1989, Gerasimova 1990, Pakhomov et al. 1996, Gaskett et al. 2001, Pusch et al. 2004). Important parameters, such as daily rations, have only been estimated in a small number of studies (Gerasimova 1990, Pakhomov et al. 1996, Pusch et al. 2004). The predation impact of myctophids on prey species has received very little attention, with the only Southern Ocean estimates being derived for myctophid predation mortality on Antarctic krill (Williams 1985, Pakhomov et al. 1996, Pusch et al. 2004).

The northern Scotia Sea area is one of the most productive regions in the Southern Ocean (Atkinson et al. 2001) and, although generally krill-dominated, has a substantial, depth-stratified myctophid fauna that includes 15 species in 5 genera (Collins et al. 2008a). Here, we investigate the diet of the most abundant myctophid species in the mesopelagic community of the northern Scotia Sea, NW of South Georgia, during the austral autumn. An index of relative importance (IRI), which combines prey occurrence, biomass and numbers, is used to describe the diet, with comparisons undertaken by generating bootstrap confidence intervals. Vertical distributions of prey species are compared with vertical distributions of myctophids to examine the degree of overlap between predators and prey and to determine whether there is a degree of prey selectivity. The impact of myctophids on assemblages of prey species was estimated and sensitivity analyses were run to provide confidence intervals around these estimates and to highlight parameters that require further attention.

\section{MATERIALS AND METHODS}

Oceanographic, acoustic and biological data were collected in the northern Scotia Sea NW of South Georgia during RRS 'James Clark Ross' Cruise 100 between 12 March and 2 April 2004. The study area is between the mean locations of the Antarctic Polar Front (APF) and the Southern Antarctic Circumpolar Current Front (SACCF).

Five acoustic transects, running from east to west, were undertaken with net hauls targeting acoustically detected putative aggregations of fish. In addition, 3 stations ( $\mathrm{A}, \mathrm{B}$ and $\mathrm{C}$ ) were studied intensively during the cruise (Fig. 1). Stns A and B were within the known foraging area of Antarctic fur seals, with Stn A over the shelf break at approximately $53^{\circ} 30^{\prime} \mathrm{S}, 37^{\circ} 30^{\prime} \mathrm{W}$ (water depth $\sim 1000 \mathrm{~m}$ ) and Stn B north of the shelf break at approximately $53^{\circ} 20^{\prime} \mathrm{S}, 38^{\circ} \mathrm{W}$ (depth $\sim 2500 \mathrm{~m}$ ). Stn C was located at an oceanic site (depth $3750 \mathrm{~m}$ ) that has been sampled repeatedly over the past decade by a Longhurst-Hardy Plankton Recorder (LHPR) (Ward et al. 2006).

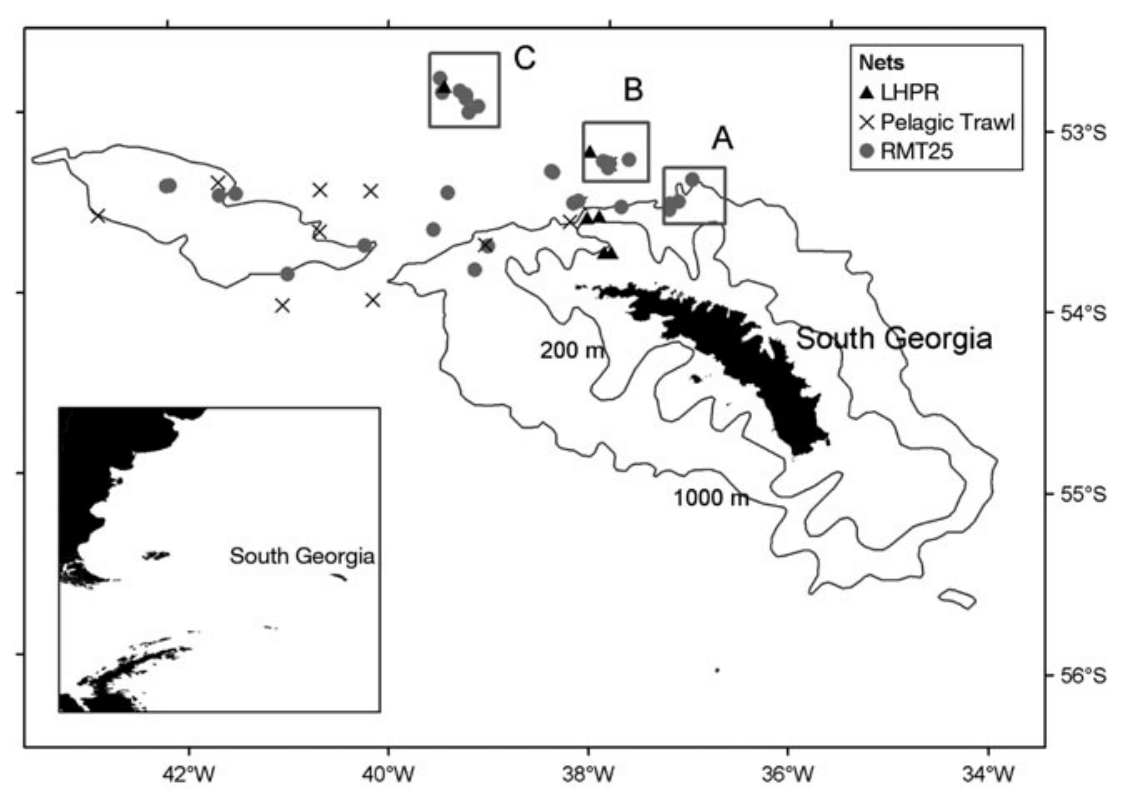

Fig. 1. Locations of $25 \mathrm{~m}^{2}$ rectangular midwater trawls (RMT25), pelagic trawls and Longhurst-Hardy Plankton Recorder (LHPR) deployments. Stns A, B and C (boxed areas) show the 3 main oceanographic regions targeted. Stn A was over the shelf break (water depth $<1000 \mathrm{~m}$ ), B was north of the shelf break, (depth around $2500 \mathrm{~m}$ ) and $\mathrm{C}$ was in oceanic water (depth around $3750 \mathrm{~m}$ ). Insert shows larger geographical area 
Net sampling. Targeted net hauls were undertaken along the acoustic transects using an opening and closing $25 \mathrm{~m}^{2}$ rectangular midwater trawl (RMT25) and an International Young Gadoid Pelagic Trawl (IYGPT) (see Collins et al. 2008a). To determine the vertical distribution of the nekton community, Stns A, B \& C (Fig. 1) were fished intensively with depth stratified RMT25 hauls (surface to 200 m, 200-400 m, 400-600 m, 600-800 $\mathrm{m}$ and 800-1000 m) repeated day and night. The abundance and depth distribution of the zooplankton prey were characterised by oblique LHPR tows to $1000 \mathrm{~m}$ made during nighttime and early dawn. The details of hauls and analyses are covered in Ward et al. (2006). Briefly, the LHPR was equipped with a $380 \mathrm{~mm}$ diameter nose cone and a $200 \mu \mathrm{m}$ mesh net and filtering gauzes. The sampler's gauze advance mechanism was set to $90 \mathrm{~s}$, which resulted in a depth resolution of around $20 \mathrm{~m}$ per patch. Samples were frozen at $-20^{\circ} \mathrm{C}$ and transported back to the UK where they were thawed and the species identified and enumerated under a stereomicroscope at $10 \times$ magnification. Counts were averaged into the same depth horizons as used for the above RMT hauls to enable appropriate comparisons between the sample sets.

Sample processing. Net haul catches were sorted to the lowest taxonomic level using published guides (Hulley 1981, Hulley 1990, Boltovskoy 1999). Fish were separated from invertebrates and measured (standard length, SL, to the nearest $\mathrm{mm}$ ). Stomachs were dissected from a sub-sample of the 9 most abundant myctophid species (Electrona carlsbergi, E. antarctica, Gymnoscopelus fraseri, G. nicholsi, G. braueri, Protomyctophum bolini, P. choriodon, Krefftichthys anderssoni and Nannobrachium achirus (see Collins et al. 2008a), and the stomach with contents frozen for subsequent microscopic analyses. Note that Collins et al. (2008a) incorrectly used the name Lampamyctus achirus rather than Nannobrachium achirus.

Stomach content analyses. In the laboratory, stomach contents were thawed prior to being sorted into species or taxonomic groups. Contents were identified to the lowest taxonomic level the state of digestion would allow. Individual prey items were weighed. If the prey was highly disaggregated, the weights of the component species were estimated as a proportion of the total contents weight. Items that were completely undigested were considered to represent trawl feeding and were excluded from subsequent analyses.

Diet was expressed using percent mass (\%M), percent frequency of occurrence $(\% \mathrm{~F})$, percent number $(\% \mathrm{~N})$ and percent Index of Relative Importance (\%IRI: see Cortes 1997). Percent mass was based on the weight of prey found in the stomach and not on reconstituted mass. The \%IRI was calculated for prey species and \% IRI $I_{D C}$ for prey categories (amphipods, cope- pods, decapods, euphausiids, mysids, unidentified crustacea, salps and molluscs). Note that \%IRI is not additive, so the sum of the individual species' \%IRI values is not the same as the prey category $\% \mathrm{IRI}_{\mathrm{DC}}$ value (see Hansson 1998). The \%IRI was calculated as:

$$
\% \operatorname{IRI}_{i}=\frac{\left(\% \mathrm{~N}_{i}+\% \mathrm{M}_{i}\right) \times \% \mathrm{~F}_{i}}{\sum_{i=1}^{n}\left(\% \mathrm{~N}_{i}+\% \mathrm{M}_{i}\right) \times \% \mathrm{~F}_{i}} \times 100
$$

Confidence limits for the \% IRI of each prey category were obtained using a bootstrap technique, whereby each species dataset (individual stomachs) was resampled (with replacement) 1000 times (see Main et al. 2009).

Analysis of feeding guilds in the myctophid community. Similarities in the diets of the myctophid species were investigated using the Plymouth Routines in Multivariate Ecological Research (PRIMER v.6) software package (Clarke \& Warwick 2001, Clarke \& Gorley 2006). Values of \%IRI for each of the dietary components (excluding unidentified crustaceans) for each fish species were square-route transformed. Nannobrachium achirus was excluded because sample numbers were insufficient (see Table 2). Bray-Curtis similarities were then calculated for each pair of fish species to produce a similarity matrix, which was classified by hierarchical agglomerative cluster analysis using the group average linking method. A SIMPER routine was applied to the resulting clusters to determine which prey species contributed to which grouping.

Determination of impact of myctophids on prey species assemblages. We used the following function to evaluate the proportion of the productivity of different prey species consumed by each myctophid species:

$$
I_{i, j}=\frac{N_{i, j} \cdot C_{i} \cdot P_{j} \cdot 24 / G}{Z_{i} \cdot F_{i}}
$$

where $I_{i, j}$ is the proportion of the production of prey species $i$ consumed by myctophid species $j$ per day, $N_{i, j}$ is the number of individuals of prey species $i$ in the stomach of myctophid species $j, C_{i}$ is the carbon mass of species $i, P_{j}$ is the depth-integrated concentration (ind. $\mathrm{m}^{-2}$ ) of predator species $j, G$ is the gut passage time (in h), $Z_{i}$ is the depth-integrated concentration (ind. $\mathrm{m}^{-2}$ ) of prey species $i$ and $F_{i}$ is the growth rate of species $i\left(\mu \mathrm{g} \mathrm{C} \mathrm{d}^{-1}\right)$.

There are a number of ways of calculating values for these parameters. Our approach was to run the calculation of each prey species $i$ consumed by each myctophid species $j 3$ times: the first time to derive our best estimate, the second time to derive an upper bound value and the third time to derive a lower bound value. The upper bound is based on (1) our upper estimate of the number of prey items $i$ eaten by myctophid spe- 
cies $j_{1}$ (2) our upper estimated concentration of $j,(3)$ our lower estimated concentration of $i$ and (4) the fastest gut passage time. Conversely, the lower bound value combines (1) our lower estimate of the number of species $i$ in the stomachs of myctophid species $j$, (2) our lower estimated concentration of $j_{1}$ (3) our upper estimated concentration of $i$ and (4) the slowest gut passage time. We detail below how these values were derived for each parameter:

Numbers of individuals of prey species i in myctophid $\boldsymbol{j}\left(\boldsymbol{N}_{i, j}\right)$ : The dataset was restricted to the 9 most common taxa found in myctophid stomachs: the amphipod Themisto gaudichaudii, the euphausiids Euphausia frigida, E. superba and Thysanoessa spp., the copepods Metridia spp., Calanoides acutus, Rhincalanus gigas and Calanus simillimus, and salps. Seven myctophid species were considered in our analysis: Electrona carlsbergi, E. antarctica, Gymnoscopelus fraseri, G. nicholsi, G. braueri, Protomyctophium bolini, and P. choriodon. Krefftichthys anderssoni and Nannobrachium achireus were excluded due to small sample size.

The data were non-normally distributed, so a nonparametric bootstrapping technique was used to generate upper and lower bounds. For each myctophid species, 30 individuals were randomly extracted and the average number of items of each prey species in this random data set was determined. This process was repeated 100 times. The median of this series was used as our best estimate value, the 25 th percentile value as the lower bound and the 75th percentile value as the upper bound.

Depth-integrated concentration of myctophid species $\left(\boldsymbol{P}_{j}\right)$ : Myctophid concentrations were evaluated from RMT25 catches. Over the course of the cruise, 4 major RMT25 sampling series were carried out, 2 during the day and 2 at night. During each series, the entire water column between 0 and $1000 \mathrm{~m}$ was sampled in $200 \mathrm{~m}$ depth intervals. Net catch concentrations (ind. $\mathrm{m}^{-3}$ ) were multiplied by the respective depth interval (m) and combined to give a depth integrated concentration per net (ind. $\mathrm{m}^{-2}$ ) between 0 and $1000 \mathrm{~m}$ for the 4 net sampling series. Our best estimate value was the median of the 4 values, with the 75 th percentile the upper bound and the 25th percentile the lower bound.

Depth-integrated concentration of prey species $\left(Z_{i}\right)$ : Two LHPR deployments between 0 and $1000 \mathrm{~m}$ were carried out during the cruise. The LHPR provides a depth resolution of between 10 and $20 \mathrm{~m}$, with each interval being sampled for an equal amount of time, filtering similar volumes of water. Accordingly, data were averaged over all depth-discrete samples to obtain a mean concentration (ind. $\mathrm{m}^{-3}$ ), and then multiplied by 1000 to give a depth-integrated concentration (ind. $\mathrm{m}^{-2}$ ). Our best estimate was determined from averaging concentrations of each respective zooplank- ton species over the 2 deployments. The lower of the 2 values was used as the lower bound value, the higher value as the upper bound value.

Growth rate of prey species $\left(F_{i}\right)$ : Species-specific growth rates $\left(\mu \mathrm{g} \mathrm{C} \mathrm{d}^{-1}\right.$ ) were estimated from direct measurements of the carbon weight, multiplied by the weight-specific growth rate of each species according to Hirst et al. (2003). Carbon weight measurements were made on 5 to 10 individuals of each species. Hirst et al. (2003) provided functions to estimate the weightspecific growth rate of zooplankton based on individual carbon weight and temperature $\left( \pm 5^{\circ} \mathrm{C}\right)$. For the copepod species (Calanoides acutus, Calanus simillimus and Rhincalanus gigas), we used a function appropriate for adult broadcast spawning copepods at $5^{\circ} \mathrm{C}$; for the euphausiids (Euphausia superba, E. frigida and Thysanoessa spp.) and the amphipod Themisto gaudichaudii, a function covering all crustaceans (excluding copepods) at $5^{\circ} \mathrm{C}$ was used, while a function for Thaliaceans at $15^{\circ} \mathrm{C}$ was used for the salps (a function for $5^{\circ} \mathrm{C}$ was not available given the lack of suitable data at lower temperatures).

Gut passage time (G): Pakhomov et al. (1996) provided data on the gut passage time of a number of different planktivorous fish species mainly feeding on mesozooplankton species from a variety of locations with different ambient temperatures. Our examination of these data showed that there was distinct temperature dependence in the gut passage time of planktivorous fish that was best explained by a negative exponential curve, with an intercept $(c)$ lower than zero. An exponential model that includes a term for the lower temperature limit $(c)$ is:

$$
y=c+a^{(-b x)}
$$

The model is fitted using least squares, i.e. estimates of $a, b$ and $c$ are found that minimise the sums of squares of the deviations from the fitted model. A conspicuous feature of the relationship between gut passage time and temperature is the increased variation at lower temperature. This was allowed for by using weighted least squares in which the more variable points are given less weight. Here, we assumed that the standard deviation of passage time increases in proportion to the mean passage time. The model was fitted using the statistical package Genstat, giving values and standard errors (SE) of: $a=24.92$ ( $\mathrm{SE}=5.72$ ), $b=0.265(\mathrm{SE}=0.065), c=4.50(\mathrm{SE}=0.630)$. Fitted values and $95 \%$ confidence limits were calculated for temperatures in the range of -1 to $22^{\circ} \mathrm{C}$ in steps of $0.1^{\circ} \mathrm{C}$ (Fig. 2).

Excluding the surface mixed layer (between 3 and $4^{\circ} \mathrm{C}$ ), temperature profiles at the time of the study (Collins et al. 2008a) varied from around 1.3 to $1.9^{\circ} \mathrm{C}$. Taking a characteristic temperature of $1.75^{\circ} \mathrm{C}$ would 


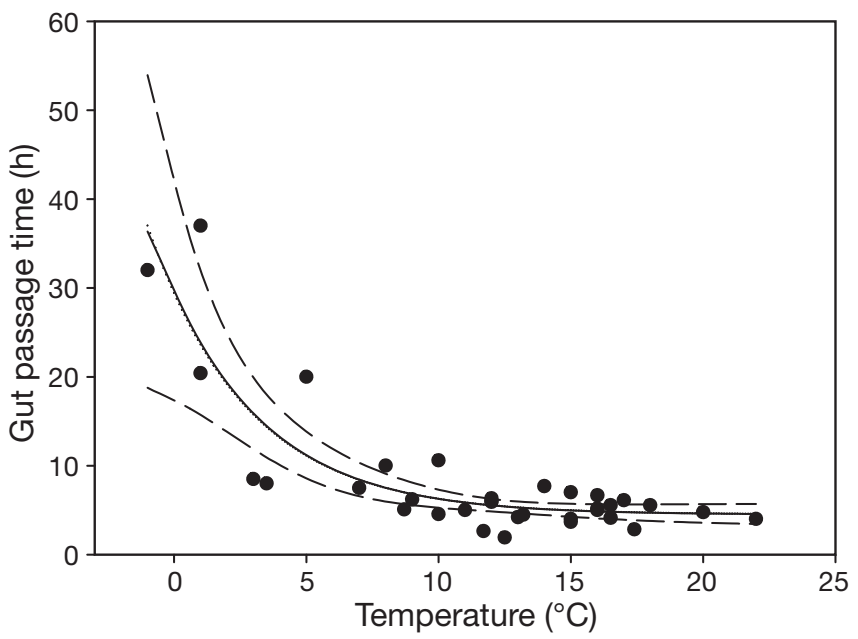

Fig. 2. Exponential curve (solid line) fitted to the relationship between gut passage time and temperature in planktivorous fishes (with lower asymptote), with upper and lower 95\% confidence interval (dashed lines). Data from Pakhomov et al. (1996)

\section{Abundance and vertical distribution of zooplankton}

Best-estimates of macrozooplankton depth-integrated abundance varied between 21 ind. $\mathrm{m}^{-2}$ for Euphausia superba to 31500 ind. $\mathrm{m}^{-2}$ for Thysanoessa spp. (Table 1). The euphausiids were mainly found in the upper water column above $600 \mathrm{~m}$ (Fig. 4). Thysanoessa spp. were found mainly concentrated above $200 \mathrm{~m}$. Euphausia frigida and E. superba were found a little deeper in the water column, at a modal depth between 200 and $400 \mathrm{~m}$. The amphipod Themisto gaudichaudii, which had a depth-integrated abundance of 364 ind. $\mathrm{m}^{-2}$, was principally found in the upper $200 \mathrm{~m}$. Salps were found mainly above $400 \mathrm{~m}$ and had a depthintegrated abundance of 2688 ind. $\mathrm{m}^{-2}$.

Copepods occurred at higher concentrations than macrozooplankton, with best estimates of depthintegrated concentrations typically ranging between $10^{5}$ and $10^{6}$ ind. $\mathrm{m}^{-2}$ (Table 1 ). The numerically dominant species were Oithona spp., Ctenocalanus spp., equate to a gut passage time of $20.2 \mathrm{~h}$, which we applied as our best estimate value. 95\% confidence intervals fitted to Eq. (3) give a fastest gut passage time of $14.3 \mathrm{~h}$ and a slowest gut passage time of $26.0 \mathrm{~h}$. This level of variance in passage time simulates to a degree the variance in gut passage time between prey species, as described by Andersen (1999) and Andersen \& Beyer (2008). More intensive investigations of speciesspecific gut passage times for Southern Ocean zooplankton would be needed to constrain these estimates further.

\section{RESULTS}

\section{Myctophid distribution}

A detailed analysis of the distribution of the myctophid species is given in Collins et al. (2008a) and only nighttime vertical distribution is illustrated here (Fig. 3). Three species had a restricted vertical distribution, with Electrona carlsbergi and Protomyctophum bolini caught primarily between 200 and $400 \mathrm{~m}$ and Protomyctophum choriodon caught in the upper $200 \mathrm{~m}$. Nannobrachium achirus was primarily caught below $600 \mathrm{~m}$, whilst all other species were caught throughout the sampled depth range. Note that sampling depths were arbitrary and thus may not have resolved vertical distributions of the species.
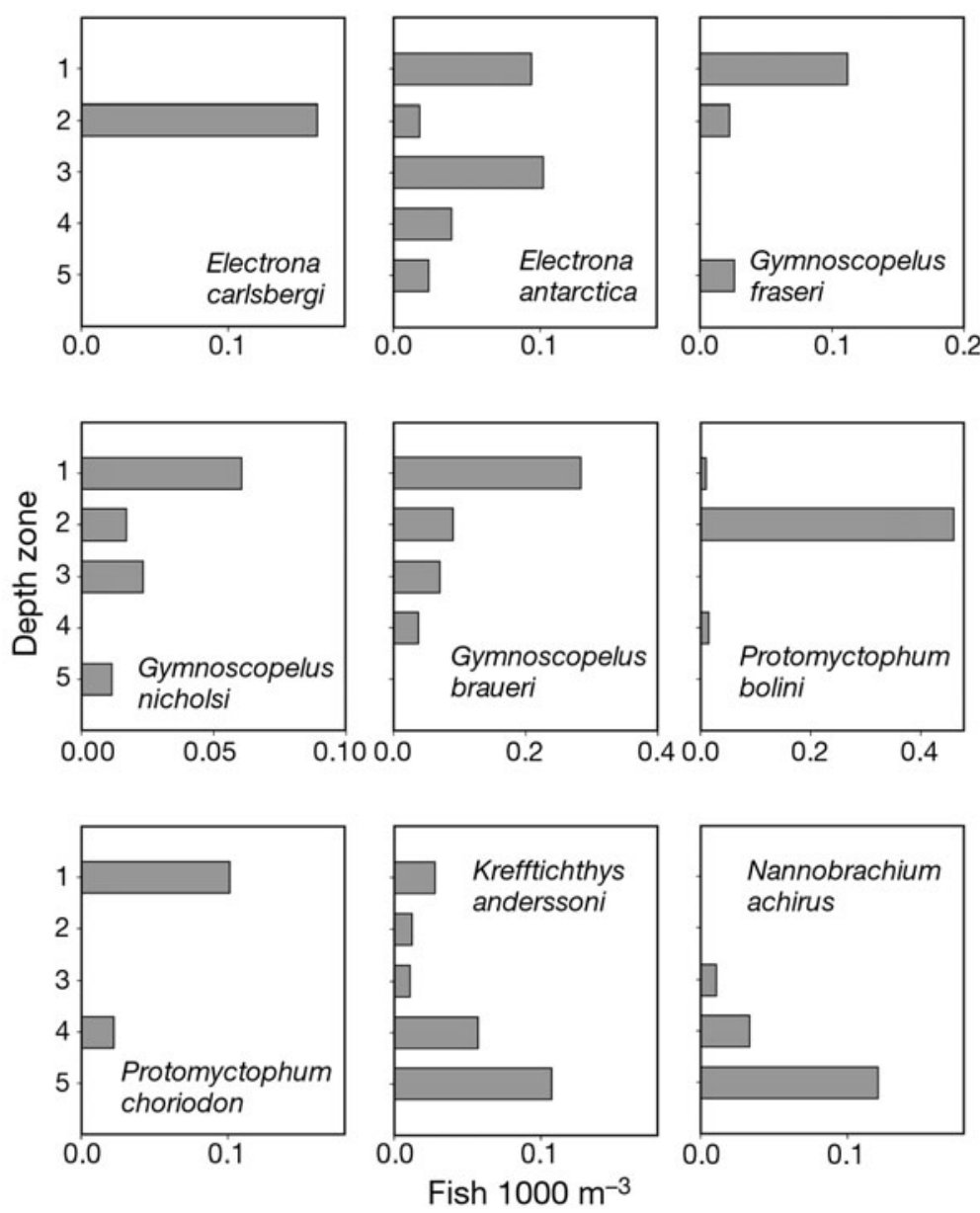

Fig. 3. Nighttime vertical distribution of myctophid fish caught in non-target RMT25 net hauls. Depth zones are 1: 0-200 m; 2: 200-400 m; 3: 400-600 m; 4: 600-800 m; 5: 800-1000 m. Modified from Collins et al. (2008a) 
Table 1. Depth-integrated $(0-1000 \mathrm{~m})$ net-catch concentration of the most abundant fish and zooplankton taxa NW of South Georgia in March-April 2004. There are 3 estimates for each prey species, representing a best estimate (median, bold) and the lower and upper bounds (25th and 75th percentile respectively).

\begin{tabular}{|llrrr|}
\hline \multirow{2}{*}{ Taxon } & \multicolumn{3}{l}{$\begin{array}{l}\text { Sampling } \\
\text { device }\end{array}$} & \multicolumn{3}{l}{ Concentration (ind. $\mathrm{m}^{-2}$ ) } \\
& & \multicolumn{1}{c}{ Best } & Upper \\
\hline Electrona carlsbergi & RMT25 & 0.02 & $\mathbf{0 . 0 4}$ & 0.06 \\
E. antarctica & RMT25 & 0.04 & $\mathbf{0 . 0 5}$ & 0.06 \\
Gymnoscopelus fraseri & RMT25 & 0.03 & $\mathbf{0 . 0 5}$ & 0.07 \\
G. nicholsi & RMT25 & 0.02 & $\mathbf{0 . 0 2}$ & 0.02 \\
G. braueri & RMT25 & 0.04 & $\mathbf{0 . 0 5}$ & 0.09 \\
Protomyctophum bolini & RMT25 & 0.06 & $\mathbf{0 . 1 0}$ & 0.13 \\
P. choriodon & RMT25 & 0.02 & $\mathbf{0 . 0 2}$ & 0.03 \\
Themisto gaudichaudii & LHPR & 51.8 & $\mathbf{3 6 4 . 4}$ & 677.0 \\
Euphausia frigida & LHPR & 303.4 & $\mathbf{1 1 2 4 . 1}$ & 1944.7 \\
E. superba & LHPR & 0.00 & $\mathbf{2 1 . 3}$ & 42.6 \\
Thysanoessa spp. & LHPR & 29603.5 & $\mathbf{3 1 4 7 6 . 7}$ & 33350.0 \\
Metridia spp. & LHPR & 6104.4 & $\mathbf{1 1 2 6 3 1 . 1}$ & 2246517.8 \\
Calanoides acutus & LHPR & 44320.9 & $\mathbf{4 5 9 1 0 . 9}$ & 47501.0 \\
Rhincalanus gigas & LHPR & 125101.3 & $\mathbf{1 7 2 7 1 2 . 3}$ & 220323.2 \\
Calanus simillimus & LHPR & 41091.1 & $\mathbf{4 6 9 2 5 . 1}$ & 52759.1 \\
Salps & LHPR & 1392.6 & $\mathbf{2 6 8 8 . 6}$ & 3984.7 \\
& & & & \\
\hline
\end{tabular}

\section{Dietary composition}

Stomach contents of 718 fish were examined microscopically (Table 2). Size ranges and depth of sampled fish reflected the size and vertical distribution of captured fish (see Table 1 in Collins et al. 2008a). Planktonic crustaceans dominated the diets of all myctophid species (Tables 3 to 6 ; Fig. 5) but, in some cases, stomach contents were too far digested to identify the specific composition. Note the large error bars around the \% IRI $\mathrm{IC}_{\mathrm{DC}}$ values for the prey categories of Krefftichthys anderssoni and Nannobrachium achirus (Fig. 5), which reflect uncertainty about the results as a consequence of the small sample sizes (Table 2).

The diet of Electrona antarctica (47 to $112 \mathrm{~mm}$ SL) was dominated by amphipods, notably the hyperiid amphipod Themisto gaudichaudii (Table 3; Fig. 5). Although E. antarctica was spread throughout the water column, T. gaudichaudii was found predominantly in the upper $200 \mathrm{~m}$, which E. antarctica

Oncaea spp. and Microcalanus spp. (Fig. 4). Oithona spp. was most numerous between 200 and $400 \mathrm{~m}$ whilst Oncaea spp. was concentrated in deeper water (600 to $1000 \mathrm{~m}$ ). Ctenocalanus spp. was found throughout the water column whilst Calanus propinquus had a bimodal peak, one at 0 to $200 \mathrm{~m}$ and another between 800 and $1000 \mathrm{~m}$. The large predatory copepod Paraeuchaeta antarctica was found in low numbers mainly between 200 and $400 \mathrm{~m}$ (Fig. 4). The larger, biomass-dominant copepods Rhincalanus gigas and Calanoides acutus were found at all depths but were concentrated at around 400 to $600 \mathrm{~m}$ and 800 to $1000 \mathrm{~m}$, respectively. Calanus simillimus was concentrated at the surface. Metridia spp. were evenly distributed throughout the water column with slightly higher abundances in the upper $400 \mathrm{~m}$. appeared to occupy during the hours of darkness only. Electrona carlsbergi, by contrast, was found only in the 200 to $400 \mathrm{~m}$ depth horizon and had a more limited size range ( 71 to $93 \mathrm{~mm} \mathrm{SL}$ ). The main prey of E. carlsbergi were copepods (Metridia spp. and Rhincalanus gigas), euphausiids, the amphipod T. gaudichaudii and salps, with T. gaudichaudii (19\% IRI) the single most important species (Table 3). E. carlsbergi was the only species found to eat significant quantities of salps.

The 3 species of Gymnoscopelus had distinctly different diets (Table 4; Fig. 5). Gymnoscopelus fraseri (46 to $112 \mathrm{~mm} \mathrm{SL}$; mean $77 \mathrm{~mm}$ ) was mostly caught in the upper $400 \mathrm{~m}$ and had a diet dominated by copepods, with Metridia spp. (mostly M. gerlachei) making up $79 \%$ IRI and Rhincalanus gigas $7 \%$ IRI. The slightly larger conspecific Gymnoscopelus braueri (46 to $133 \mathrm{~mm}$

Table 2. Myctophid fish sampled for stomach analysis. Numbers of individuals sampled in each depth layer, with mean size and size range; SL given as mean (range)

\begin{tabular}{|c|c|c|c|c|c|c|c|c|}
\hline \multirow{2}{*}{ Fish species } & \multicolumn{7}{|c|}{ Depth layer (m) } & \multirow{2}{*}{$\mathrm{SL}(\mathrm{mm})$} \\
\hline & $0-200$ & $200-400$ & $400-600$ & $600-800$ & $800-1000$ & $0-1000$ & Total & \\
\hline Electrona carlsbergi & 0 & 158 & 0 & 0 & 0 & 0 & 158 & $80(71-93)$ \\
\hline Electrona antarctica & 21 & 23 & 30 & 14 & 2 & 36 & 126 & $84(47-112)$ \\
\hline Gymnoscopelus fraseri & 25 & 26 & 5 & 0 & 0 & 0 & 56 & $77(46-112)$ \\
\hline Gymnoscopelus nicholsi & 25 & 59 & 5 & 0 & 0 & 0 & 89 & $111(52-149)$ \\
\hline Gymnoscopelus braueri & 16 & 48 & 20 & 6 & 0 & 8 & 98 & $103(46-133)$ \\
\hline Protomyctophum bolini & 2 & 58 & 1 & 0 & 0 & 0 & 61 & $49(38-78)$ \\
\hline Protomyctophum choriodon & 53 & 31 & 0 & 0 & 0 & 0 & 84 & $73(51-85)$ \\
\hline Krefftichthys anderssoni & 4 & 2 & 12 & 5 & 0 & 7 & 30 & $39(17-73)$ \\
\hline Nannobrachium achirus & 0 & 0 & 1 & 3 & 4 & 8 & 16 & $133(117-140)$ \\
\hline
\end{tabular}



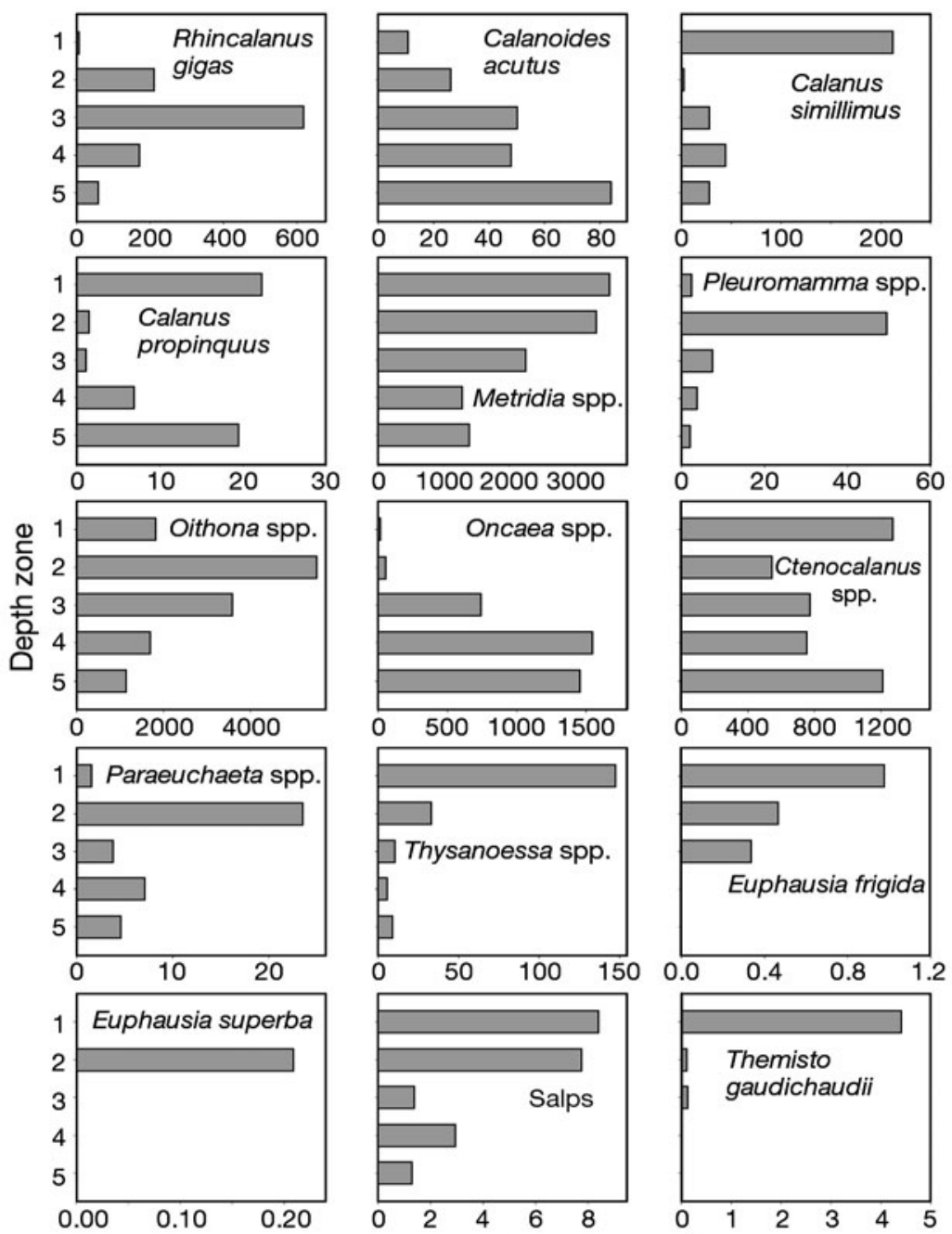

Average abundance (ind. $\mathrm{m}^{-3}$ )

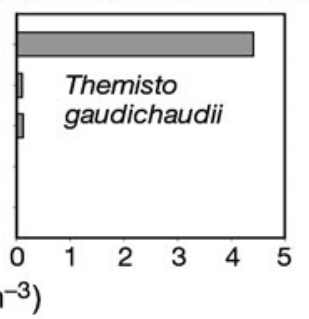

Fig. 4. Depth distribution of the key zooplankton species in the diets of myctophids in this study, and of the biomass-dominant zooplankton. Depth zones as in Fig. 3
SL; mean $103 \mathrm{~mm}$ ) reached its maximum abundance in the upper $200 \mathrm{~m}$ at night and principally consumed the amphipod Themisto gaudichaudii (56\% IRI) and Antarctic krill Euphausia superba (10\% IRI), both of which were mainly caught in the surface waters. Antarctomysis spp. (7.8\% IRI) and the copepods Metridia spp. and $R$. gigas (1\% IRI combined) also made small contributions to the diet. Gymnoscopelus nicholsi was one of the larger myctophid species sampled (52 to $144 \mathrm{~mm}$ SL; mean $111 \mathrm{~mm}$ ) and, although caught throughout the water column, reached its maximum abundance in the upper $200 \mathrm{~m}$ at night. The diet was varied and included euphausiids, copepods and amphipods with Metridia spp., T. gaudichaudii, and Euphausia frigida the most common prey species. E. superba was also consumed.

Protomyctophum bolini (38 to $78 \mathrm{~mm} \mathrm{SL;}$ mean $49 \mathrm{~mm}$ ) was mainly caught between 200 and $400 \mathrm{~m}$ and fed mostly on copepods and euphausiids (Table 5; Fig. 5). The principal prey species were the copepod Metridia spp. and Euphausia frigida, which were both abundant in the same depth zone as the fish. Protomyctophum choriodon (51 to $85 \mathrm{~mm} \mathrm{SL}$; mean $73 \mathrm{~mm}$ ) was found mainly in the top $200 \mathrm{~m}$ and was primarily a copepod consumer (Table 5), particularly of Metridia spp. and Calanoides acutus (38 and $27 \%$ IRI, respectively), but also consumed Rhincalanus gigas and Calanus simillimus (10 and 6\% IRI, respectively).

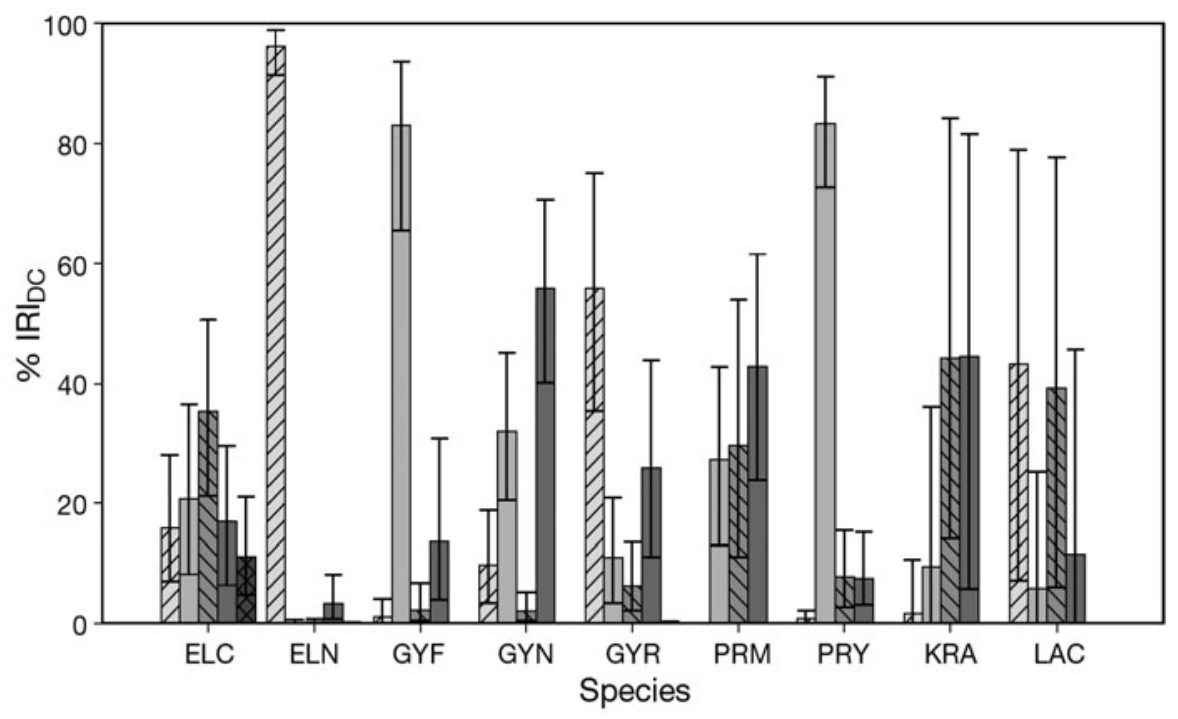

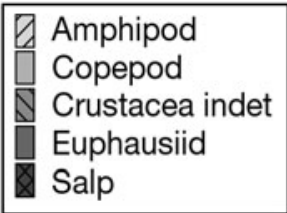

Fig. 5. Diet composition of 9 myctophid species. Proportion of diet made up of 5 key prey categories expressed as percent index of relative importance (\% IRI $\left.I_{D C}\right)$. Error bars are bootstrap $95 \%$ confidence intervals. ELC: Electrona carlsbergi; ELN: Electrona antarctica; GYF: Gymnoscopelus fraseri; GYN: Gymnoscopelus nicholsi; GYR: Gymnoscopelus braueri; PRM: Protomyctophum bolini; PRY: Protomyctophum choriodon; KRA: Krefftichthys anderssoni; LAC: Nannobrachium achirus. Crustacea indet. represents a group with visibly crustacean characters but too digested to identify further 
Table 3. Electrona carlsbergi and Electrona antarctica. Diet composition. Percent number (N), mass (M), frequency of occurrence (F) and index of relative importance (IRI) of items of each prey species are given with sums for prey categories. See 'Materials and methods' for calculation of \% IRI. Note that \% occurrence and \% IRI are not additive and that grouping the prey into categories influences the resulting $\% \mathrm{IRI}_{\mathrm{DC}}$ values

\begin{tabular}{|c|c|c|c|c|c|c|c|c|}
\hline \multirow{2}{*}{ Prey } & \multicolumn{4}{|c|}{ Electrona carlsbergi } & \multicolumn{4}{|c|}{ Electrona antarctica } \\
\hline & $\% \mathrm{~N}$ & $\% \mathrm{M}$ & $\% \mathrm{~F}$ & $\%$ IRI & $\% \mathrm{~N}$ & $\% \mathrm{M}$ & $\% \mathrm{~F}$ & $\%$ IRI \\
\hline \multicolumn{9}{|l|}{ Amphipoda } \\
\hline Themisto gaudichaudii & 9.61 & 26.96 & 20.89 & 19.48 & 70.97 & 80.65 & 84.25 & 98.78 \\
\hline Total & 9.61 & 26.96 & 20.89 & 15.47 & 70.97 & 80.65 & 84.25 & 96.51 \\
\hline \multicolumn{9}{|l|}{ Copepoda } \\
\hline Calanoides acutus & 13.92 & 1.72 & 6.33 & 2.53 & 0.00 & 0.00 & 0.00 & 0.00 \\
\hline Calanus propinquus & 0.20 & 0.02 & 0.63 & 0.00 & 0.00 & 0.00 & 0.00 & 0.00 \\
\hline Calanus simillimus & 10.98 & 1.36 & 3.80 & 1.20 & 1.21 & 0.04 & 0.79 & 0.01 \\
\hline Heterorhabdus spp. & 0.20 & 0.02 & 0.63 & 0.00 & 0.00 & 0.00 & 0.00 & 0.00 \\
\hline Metridia spp. & 10.00 & 0.40 & 14.56 & 3.86 & 0.00 & 0.00 & 0.00 & 0.00 \\
\hline Oithona spp. & 0.20 & 0.01 & 0.63 & 0.00 & 0.00 & 0.00 & 0.00 & 0.00 \\
\hline Paraeuchaeta spp. & 0.78 & 0.16 & 2.53 & 0.06 & 3.22 & 0.60 & 3.15 & 0.06 \\
\hline Pleuromamma spp. & 0.59 & 0.07 & 1.90 & 0.03 & 0.00 & 0.00 & 0.00 & 0.00 \\
\hline Rhincalanus gigas & 10.00 & 2.06 & 8.23 & 2.53 & 0.00 & 0.00 & 0.00 & 0.00 \\
\hline Unidentified copepods & 0.20 & 0.01 & 0.63 & 0.00 & 0.00 & 0.00 & 0.00 & 0.00 \\
\hline Total & 47.06 & 5.85 & 20.25 & 21.71 & 4.44 & 0.64 & 3.94 & 0.15 \\
\hline \multicolumn{9}{|l|}{ Euphausiacea } \\
\hline Euphausia frigida & 0.20 & 0.40 & 0.63 & 0.01 & 1.61 & 3.64 & 2.36 & 0.10 \\
\hline Euphausia superba & 0.59 & 7.15 & 1.90 & 0.37 & 1.61 & 4.46 & 1.57 & 0.07 \\
\hline Euphausia triacantha & 0.00 & 0.00 & 0.00 & 0.00 & 1.61 & 4.01 & 2.36 & 0.10 \\
\hline Thysanoessa spp. & 0.78 & 0.54 & 2.53 & 0.09 & 0.40 & 0.09 & 0.79 & 0.00 \\
\hline Unidentified euphausiids & 8.24 & 25.05 & 15.19 & 12.90 & 13.31 & 3.95 & 4.72 & 0.63 \\
\hline Total & 9.80 & 33.16 & 20.25 & 17.62 & 18.55 & 16.16 & 11.81 & 3.10 \\
\hline \multicolumn{9}{|l|}{ Unidentified crustaceans } \\
\hline Total & 14.51 & 26.82 & 41.14 & 34.44 & 2.82 & 2.47 & 5.51 & 0.22 \\
\hline \multicolumn{9}{|l|}{ Salps } \\
\hline Total & 19.02 & 7.21 & 20.25 & 10.76 & 3.23 & 0.09 & 0.79 & 0.02 \\
\hline
\end{tabular}

The sample size of both Krefftichthys anderssoni and Nannobrachium achirus was small, and a large proportion of the stomach contents could not be identified beyond the classification of Crustacea (Table 6). K. anderssoni, which was most abundant in the 600 to $1000 \mathrm{~m}$ depth layer, was one of the smaller species studied (17 to $73 \mathrm{~mm} \mathrm{SL}$; mean $39 \mathrm{~mm}$ ) and fed principally on the euphausiid Thysanoessa spp. (24\% IRI), which was found predominately in the top $400 \mathrm{~m}$. N. achirus (mean SL $133 \mathrm{~mm}$ ) was mainly caught deeper than $600 \mathrm{~m}$ and principally ate Themisto gaudichaudii (48\% IRI), along with some Antarctic krill (3\% IRI).

Grouping all myctophids species together, there was a clear change in diet with size (Fig. 6). Smaller fish ( $<75 \mathrm{~mm}$ SL) consumed significantly more copepods ( $62 \% \mathrm{IRI}_{\mathrm{DC}}$ ) than the larger size classes, with the older copepodite stages predominating. Specifically, most of the consumed Calanoides acutus were Copepodite stage CV, Metridia spp. were Stage CVI females, Rhincalanus gigas were Stage CIII to CVI females and Calanus simillimus were Stage CV and CVI males and females. There was a greater range of Paraeuchaeta antarctica developmental stages, with stages from CII upwards being found, although Stage CV and CVI females and males were the most abundant. Amphipods, such as Themisto gaudichaudii, were the most abundant dietary item $\left(43 \%\right.$ IRI $\left._{\text {DC }}\right)$ in mediumsized ( 76 to $100 \mathrm{~mm}$ SL) myctophids, while copepods (43\% IRI $\left.\mathrm{IC}_{\mathrm{DC}}\right)$ were also taken. Euphausiids, including Antarctic krill, were only a major component (45\% IRI $_{\mathrm{DC}}$ ) of the diet of fish larger than $100 \mathrm{~mm} \mathrm{SL}$.

\section{Feeding guild analysis}

Hierarchical cluster analysis (excluding the prey category 'unidentified crustacea') produced 5 clusters at the $60 \%$ similarity level; however, 2 of them (Clusters 2 and 5) consisted of single species (Fig. 7). Cluster 2 grouped Gymnoscopelus braueri and Electrona antarctica together in a cluster dominated by the consumption of Themisto gaudichaudii (83\% contribution). Clusters 3 and 4 were both dominated by copepod feeders, with Gymnoscopelus fraseri and Protomyctophum choriodon in a cluster dominated by Metridia spp. (40\%) and Rhincalanus gigas (16\%) and Gymnoscopelus nicholsi and Protomyctophum bolini in a cluster that mainly consumed Metridia spp. (32\%) and Euphausia frigida (21\%). 
Table 4. Gymnoscopelus fraseri, Gymnoscopelus nicholsi and Gymnoscopelus braueri. Diet composition. Percent number (N), mass (M) frequency of occurrence (F) and index of relative importance (IRI) of items of each prey species are given with sums for prey categories. See 'Materials and methods' for calculation of \% IRI. Note that \% occurrence and \% IRI are not additive and that grouping the prey into categories influences the resulting $\operatorname{IRI}_{\mathrm{DC}}$ values

\begin{tabular}{|c|c|c|c|c|c|c|c|c|c|c|c|c|}
\hline \multirow[t]{2}{*}{ Prey } & \multicolumn{4}{|c|}{ Gymnoscopelus fraseri } & \multicolumn{4}{|c|}{ Gymnoscopelus nicholsi } & \multicolumn{4}{|c|}{ Gymnoscopelus braueri } \\
\hline & $\% \mathrm{~N}$ & $\% \mathrm{M}$ & $\% \mathrm{~F}$ & $\%$ IRI & $\% \mathrm{~N}$ & $\% \mathrm{M}$ & $\% \mathrm{~F}$ & $\%$ IRI & $\% \mathrm{~N}$ & $\% \mathrm{M}$ & $\% \mathrm{~F}$ & $\%$ IRI \\
\hline \multicolumn{13}{|l|}{ Amphipoda } \\
\hline Themisto gaudichaudii & 0.63 & 8.23 & 8.93 & 1.32 & 3.98 & 29.47 & 24.72 & 19.48 & 28.51 & 43.55 & 47.96 & 73.49 \\
\hline Total & 0.63 & 8.23 & 8.93 & 0.88 & 3.98 & 29.47 & 24.72 & 9.36 & 28.51 & 43.55 & 47.96 & 56.03 \\
\hline \multicolumn{13}{|l|}{ Copepoda } \\
\hline Aetedius spp. & 0.00 & 0.00 & 0.00 & 0.00 & 0.12 & 0.03 & 1.12 & 0.00 & 0.00 & 0.00 & 0.00 & 0.00 \\
\hline Calanoides acutus & 2.20 & 2.98 & 16.07 & 1.39 & 2.65 & 0.46 & 13.48 & 0.99 & 0.80 & 0.04 & 1.02 & 0.02 \\
\hline Calanus propinquus & 0.08 & 0.11 & 1.79 & 0.01 & 0.24 & 0.04 & 2.25 & 0.01 & 0.00 & 0.00 & 0.00 & 0.00 \\
\hline Calanus simillimus & 1.18 & 1.60 & 12.50 & 0.58 & 6.39 & 1.00 & 17.98 & 3.13 & 3.61 & 0.20 & 5.10 & 0.41 \\
\hline Candacia sp. & 0.08 & 0.21 & 1.79 & 0.01 & 0.36 & 0.09 & 2.25 & 0.02 & 0.40 & 0.04 & 1.02 & 0.01 \\
\hline Drepanopus forcipatus & 0.08 & 0.04 & 1.79 & 0.00 & 0.00 & 0.00 & 0.00 & 0.00 & 0.80 & 0.01 & 1.02 & 0.02 \\
\hline Gaidius tenuispinus & 0.08 & 0.11 & 1.79 & 0.01 & 0.00 & 0.00 & 0.00 & 0.00 & 0.00 & 0.00 & 0.00 & 0.00 \\
\hline Haloptolis sp. & 0.08 & 0.11 & 1.79 & 0.01 & 0.00 & 0.00 & 0.00 & 0.00 & 0.00 & 0.00 & 0.00 & 0.00 \\
\hline Heterorhabdus spp. & 0.31 & 0.43 & 3.57 & 0.04 & 0.96 & 0.15 & 3.37 & 0.09 & 0.00 & 0.00 & 0.00 & 0.00 \\
\hline Metridia spp. & 82.20 & 33.58 & 41.07 & 79.59 & 38.55 & 2.00 & 35.96 & 34.36 & 20.48 & 0.37 & 9.18 & 4.07 \\
\hline Oithona spp. & 0.00 & 0.00 & 0.00 & 0.00 & 0.12 & 0.01 & 1.12 & 0.00 & 0.00 & 0.00 & 0.00 & 0.00 \\
\hline Paraeuchaeta spp. & 0.86 & 4.18 & 8.93 & 0.75 & 0.60 & 0.28 & 5.61 & 0.08 & 2.81 & 0.26 & 2.04 & 0.13 \\
\hline Pleuromamma spp. & 0.55 & 0.64 & 7.14 & 0.14 & 1.45 & 0.17 & 7.87 & 0.30 & 2.01 & 0.09 & 5.10 & 0.23 \\
\hline Rhincalanus gigas & 4.00 & 12.30 & 25.00 & 6.82 & 6.87 & 1.71 & 21.35 & 4.31 & 7.63 & 0.58 & 8.16 & 1.43 \\
\hline Unidentified calanoid copepods & 1.10 & 1.49 & 1.79 & 0.08 & 0.48 & 0.05 & 3.37 & 0.04 & 0.00 & 0.00 & 0.00 & 0.00 \\
\hline Unidentified copepods & 0.00 & 0.00 & 0.00 & 0.00 & 0.24 & 0.05 & 1.12 & 0.01 & 1.20 & 1.00 & 3.06 & 0.14 \\
\hline Total & 92.78 & 57.77 & 50.00 & 84.11 & 59.04 & 6.03 & 43.82 & 32.28 & 39.76 & 2.59 & 16.33 & 11.21 \\
\hline \multicolumn{13}{|l|}{ Decapoda } \\
\hline Unidentified decapods & 0.00 & 0.00 & 0.00 & 0.00 & 0.00 & 0.00 & 0.00 & 0.00 & 0.40 & 0.93 & 1.02 & 0.03 \\
\hline Gennadus spp. & 0.00 & 0.00 & 0.00 & 0.00 & 0.00 & 0.00 & 0.00 & 0.00 & 1.20 & 3.90 & 2.04 & 0.22 \\
\hline Total & 0.00 & 0.00 & 0.00 & 0.00 & 0.00 & 0.00 & 0.00 & 0.00 & 1.61 & 4.84 & 3.06 & 0.32 \\
\hline \multicolumn{13}{|l|}{ Euphausiacea } \\
\hline Euphausia frigida & 1.49 & 3.79 & 10.71 & 0.95 & 14.34 & 15.04 & 20.22 & 14.00 & 2.81 & 0.56 & 4.08 & 0.29 \\
\hline Euphausia superba & 0.00 & 0.00 & 0.00 & 0.00 & 1.08 & 22.66 & 6.74 & 3.77 & 5.62 & 36.58 & 11.22 & 10.07 \\
\hline Euphausia triacantha & 0.00 & 0.00 & 0.00 & 0.00 & 0.00 & 0.00 & 0.00 & 0.00 & 0.40 & 0.19 & 1.02 & 0.01 \\
\hline Thysanoessa spp. & 1.65 & 13.48 & 7.14 & 1.81 & 9.28 & 6.83 & 15.73 & 5.97 & 5.22 & 0.98 & 6.12 & 0.81 \\
\hline Unidentified euphausiids & 2.20 & 8.51 & 19.64 & 3.52 & 7.83 & 11.55 & 20.22 & 9.23 & 3.61 & 3.22 & 5.10 & 0.74 \\
\hline Total & 5.33 & 25.78 & 37.50 & 13.04 & 32.53 & 56.08 & 56.18 & 56.35 & 17.67 & 41.53 & 27.55 & 26.44 \\
\hline \multicolumn{13}{|l|}{ Mysidacea } \\
\hline Antarctomysis spp. & 0.86 & 7.98 & 19.64 & 2.91 & 3.73 & 7.32 & 15.73 & 4.10 & 9.24 & 7.11 & 22.45 & 7.80 \\
\hline Total & 0.86 & 7.98 & 19.64 & 1.94 & 3.73 & 7.32 & 15.73 & 1.97 & 9.24 & 7.11 & 22.45 & 5.95 \\
\hline \multicolumn{13}{|l|}{ Ostracoda } \\
\hline Total & 0.39 & 0.25 & 0.00 & 0.03 & 0.00 & 0.00 & 0.00 & 0.00 & 0.40 & 0.07 & 0.00 & 0.01 \\
\hline $\begin{array}{l}\text { Unidentified crustaceans } \\
\text { Total }\end{array}$ & 0.00 & 0.00 & 0.00 & 0.00 & 0.48 & 1.06 & 2.25 & 0.04 & 0.00 & 0.00 & 1.02 & 0.00 \\
\hline \multicolumn{13}{|l|}{ Mollusca } \\
\hline Thecate pteropod & 0.00 & 0.00 & 0.00 & 0.00 & 0.24 & 0.04 & 2.25 & 0.02 & 1.20 & 0.04 & 1.02 & 0.03 \\
\hline Total & 0.00 & 0.00 & 3.57 & 0.00 & 0.24 & 0.04 & 2.25 & 0.01 & 1.20 & 0.04 & 1.02 & 0.02 \\
\hline \multicolumn{13}{|l|}{ Salps } \\
\hline Total & 0.00 & 0.00 & 0.00 & 0.00 & 0.00 & 0.00 & 0.00 & 0.00 & 1.61 & 0.28 & 1.02 & 0.03 \\
\hline
\end{tabular}

\section{Consumption of prey productivity}

The majority of myctophid stomachs examined contained more than one species of prey, with some fish containing 5 or more prey species. Where a prey species was present in the stomach of a myctophid, it was commonly found in numbers $>10$ or more. However, when averaged for a particular myctophid species, the number of prey items frequently became $<1$ because of the large numbers of stomachs from which a prey species was absent (Table 7). The exception were some of the copepod species, most notably Metridia spp., which were found in relatively high numbers in the stomachs of Gymnoscopelus fraseri, Krefftichthys anderssoni and Protomyctophum choriodon, such that average prey numbers per stomach were $>1$. The same 
Table 5. Protomyctophum bolini and Protomyctophum choriodon. Diet composition. Percent number (N), mass (M) frequency of occurrence (F) and index of relative importance (IRI) of items of each prey species are given with sums for prey categories. See 'Materials and methods' for calculation of \% IRI. Note that\% occurrence and \% IRI are not additive and that grouping the prey into categories influences the resulting $\operatorname{IRI}_{\mathrm{DC}}$ values

\begin{tabular}{|c|c|c|c|c|c|c|c|c|}
\hline \multirow[t]{2}{*}{ Prey } & \multicolumn{4}{|c|}{ Protomyctophum bolini } & \multicolumn{4}{|c|}{ Protomyctophum choriodon } \\
\hline & $\% \mathrm{~N}$ & $\% \mathrm{M}$ & $\% \mathrm{~F}$ & $\%$ IRI & $\% \mathrm{~N}$ & $\% \mathrm{M}$ & $\% \mathrm{~F}$ & $\%$ IRI \\
\hline \multicolumn{9}{|l|}{ Ampipoda } \\
\hline Themisto gaudichaudii & 0.00 & 0.00 & 0.00 & 0.00 & 0.65 & 5.10 & 14.29 & 1.34 \\
\hline Total & 0.00 & 0.00 & 0.00 & 0.00 & 0.65 & 5.10 & 14.29 & 0.85 \\
\hline \multicolumn{9}{|l|}{ Copepoda } \\
\hline Calanoides acutus & 1.02 & 0.41 & 1.64 & 0.05 & 27.89 & 22.11 & 33.33 & 27.18 \\
\hline Calanus propinquus & 0.51 & 0.20 & 1.64 & 0.02 & 0.19 & 0.15 & 3.57 & 0.02 \\
\hline Calanus simillimus & 3.57 & 1.42 & 4.92 & 0.52 & 8.89 & 6.00 & 23.81 & 5.78 \\
\hline Candacia sp. & 0.00 & 0.00 & 0.00 & 0.00 & 0.14 & 0.19 & 3.57 & 0.02 \\
\hline Drepanopus forcipatus & 0.00 & 0.00 & 0.00 & 0.00 & 0.19 & 0.05 & 2.38 & 0.01 \\
\hline Gaidius tenuispinus & 0.00 & 0.00 & 0.00 & 0.00 & 0.05 & 0.04 & 1.19 & 0.00 \\
\hline Heterorhabdus spp. & 1.02 & 1.29 & 1.64 & 0.08 & 0.19 & 0.15 & 3.57 & 0.02 \\
\hline Metridia spp. & 44.90 & 4.40 & 18.03 & 18.97 & 40.27 & 11.95 & 44.05 & 37.52 \\
\hline Paraeuchaeta spp. & 1.53 & 2.78 & 4.92 & 0.23 & 1.21 & 1.67 & 10.71 & 0.50 \\
\hline Pleuromamma spp. & 1.02 & 0.41 & 3.28 & 0.10 & 0.51 & 0.42 & 11.90 & 0.18 \\
\hline Rhincalanus gigas & 1.02 & 0.68 & 3.28 & 0.12 & 7.50 & 12.58 & 29.76 & 9.74 \\
\hline Scaphocalanus spp. & 0.00 & 0.00 & 0.00 & 0.00 & 0.19 & 0.15 & 1.19 & 0.01 \\
\hline Scolecithricella spp. & 0.00 & 0.00 & 0.00 & 0.00 & 0.65 & 0.52 & 1.19 & 0.02 \\
\hline Copepoda unid. & 0.51 & 0.20 & 1.64 & 0.02 & 3.82 & 3.01 & 8.33 & 0.93 \\
\hline Calanoid copepods unid. & 2.04 & 1.69 & 3.28 & 0.26 & 0.84 & 1.36 & 1.19 & 0.04 \\
\hline Total & 57.14 & 13.46 & 31.15 & 27.96 & 92.50 & 60.35 & 53.57 & 84.64 \\
\hline \multicolumn{9}{|l|}{ Euphausiacea } \\
\hline Euphausia frigida & 12.76 & 34.10 & 22.95 & 22.94 & 0.98 & 3.76 & 5.95 & 0.46 \\
\hline Thysanoessa spp. & 6.12 & 5.55 & 9.84 & 2.45 & 2.65 & 8.01 & 23.81 & 4.14 \\
\hline Euphausiid unid. & 6.12 & 11.98 & 14.75 & 5.70 & 0.84 & 2.79 & 10.71 & 0.63 \\
\hline Total & 25.00 & 51.62 & 44.26 & 43.12 & 4.47 & 14.56 & 36.90 & 7.26 \\
\hline \multicolumn{9}{|l|}{ Mysidacea } \\
\hline Antarctomysis spp. & 0.00 & 0.00 & 0.00 & 0.00 & 0.23 & 1.67 & 3.57 & 0.11 \\
\hline Total & 0.00 & 0.00 & 4.92 & 0.00 & 0.23 & 1.67 & 3.57 & 0.07 \\
\hline \multicolumn{9}{|l|}{ Ostracoda } \\
\hline Gigantocypris spp. & 0.00 & 0.00 & 0.00 & 0.00 & 0.05 & 0.01 & 1.19 & 0.00 \\
\hline Unidentified ostracods & 3.06 & 0.54 & 4.76 & 0.38 & 0.00 & 0.00 & 0.00 & 0.00 \\
\hline Total & 3.06 & 0.54 & 4.76 & 0.23 & 0.05 & 0.01 & 1.19 & 0.00 \\
\hline Unidentified crustaceans & 14.80 & 34.37 & 45.90 & 48.15 & 2.05 & 18.06 & 34.52 & 11.32 \\
\hline Total & 14.80 & 34.37 & 45.90 & 28.69 & 2.05 & 18.06 & 34.52 & 7.18 \\
\hline \multicolumn{9}{|l|}{ Mollusca } \\
\hline Limacina spp. & 0.00 & 0.00 & 0.00 & 0.00 & 0.05 & 0.24 & 1.19 & 0.01 \\
\hline Total & 0.00 & 0.00 & 0.00 & 0.00 & 0.05 & 0.24 & 1.19 & 0.00 \\
\hline
\end{tabular}

was true of Calanoides acutus, Rhincalanus gigas and Calanus simillimus in the stomachs of $P$. choriodon. Average numbers $>1$ were also found for the euphausiid Thysanoessa spp. in the stomachs of $K$. anderssoni and Gymnoscopelus nicholsi.

The best estimates of the average depth-integrated concentration of the 9 myctophid species in the upper $1000 \mathrm{~m}$ of the water column around South Georgia ranged between 0.02 and 0.1 ind. $\mathrm{m}^{-2}$ (Table 1; see also Collins et al. 2008a). As a best estimate, myctophids consumed up to $0.02 \%$ of the daily productivity (in terms of $\mathrm{C} \mathrm{m}^{-2} \mathrm{~d}^{-1}$ ) of key copepod species in the NW South Georgia region (Table 8). Protomyctophum choriodon had the largest overall impact, taking $0.01 \% \mathrm{~d}^{-1}$ of the Calanoides acutus production.

The impact of myctophid predation on macrozooplankton production was greater than that of copepods (Table 8). The myctophid community consumed a best estimate of $3.85 \%$ of Themisto gaudichaudii daily production and $6.26 \%$ of Euphausia superba daily production. The former was impacted most by Electrona antarctica and Gymnoscopelus braueri, while G. braueri and Gymnoscopelus nicholsi had the largest impact on the latter. Myctophids consumed a lower proportion of Euphausia frigida and Thysanoessa spp. productivity, accounting for $0.06 \% \mathrm{~d}^{-1}$ and $0.02 \% \mathrm{~d}^{-1}$, respectively. The impact of myctophids on salps was negligible. 
Table 6. Krefftichthys anderssonii and Nannobrachium achirus. Diet composition. Percent number (N), mass (M) frequency of occurrence (F) and index of relative importance (IRI) of items of each prey species are given with sums for prey categories. See 'Materials and methods' for calculation of \% IRI. Note that \% occurrence and \% IRI are not additive and that grouping the prey into categories influences the resulting $\mathrm{IRI}_{\mathrm{DC}}$ values

\begin{tabular}{|c|c|c|c|c|c|c|c|c|}
\hline \multirow{2}{*}{ Prey } & \multicolumn{4}{|c|}{ Krefftichthys anderssoni } & \multicolumn{4}{|c|}{ Nannobrachium achirus } \\
\hline & $\% \mathrm{~N}$ & $\% \mathrm{M}$ & $\% \mathrm{~F}$ & $\%$ IRI & $\% \mathrm{~N}$ & $\% \mathrm{M}$ & $\% \mathrm{~F}$ & $\%$ IRI \\
\hline \multicolumn{9}{|l|}{ Ampipoda } \\
\hline Themisto gaudichaudii & 1.38 & 10.70 & 3.45 & 1.19 & 20.83 & 42.38 & 25.00 & 34.35 \\
\hline Vibilia antarctica & 0.00 & 0.00 & 0.00 & 0.00 & 4.17 & 2.65 & 6.25 & 0.93 \\
\hline Amphipoda & 0.00 & 0.00 & 0.00 & 0.00 & 8.33 & 6.51 & 6.25 & 2.02 \\
\hline Total & 1.38 & 10.70 & 3.45 & 0.82 & 33.33 & 51.54 & 37.50 & 48.04 \\
\hline \multicolumn{9}{|l|}{ Copepoda } \\
\hline Calanoides acutus & 1.38 & 1.55 & 3.45 & 0.29 & 0.00 & 0.00 & 0.00 & 0.00 \\
\hline Calanus simillimus & 10.09 & 3.66 & 3.45 & 1.35 & 0.00 & 0.00 & 0.00 & 0.00 \\
\hline Candacia sp. & 0.00 & 0.00 & 0.00 & 0.00 & 4.17 & 0.43 & 6.25 & 0.62 \\
\hline Metridia spp. & 21.56 & 2.61 & 6.90 & 4.75 & 12.50 & 0.26 & 6.25 & 1.73 \\
\hline Unidentified copepods & 0.46 & 0.50 & 3.45 & 0.09 & 4.17 & 3.94 & 6.25 & 1.10 \\
\hline Total & 33.49 & 8.31 & 10.34 & 8.51 & 20.83 & 4.62 & 12.50 & 4.80 \\
\hline \multicolumn{9}{|l|}{ Euphausiacea } \\
\hline Euphausia frigida & 9.17 & 6.87 & 3.45 & 1.58 & 4.17 & 0.43 & 6.25 & 0.62 \\
\hline Euphausia superba & 0.00 & 0.00 & 0.00 & 0.00 & 4.17 & 17.55 & 6.25 & 2.95 \\
\hline Thysanoessa spp. & 38.99 & 42.24 & 10.34 & 23.97 & 4.17 & 1.46 & 6.25 & 0.76 \\
\hline Unidentified euphausiids & 7.34 & 10.92 & 6.90 & 3.59 & 0.00 & 0.00 & 0.00 & 0.00 \\
\hline Total & 55.50 & 60.03 & 20.69 & 47.06 & 12.50 & 19.43 & 18.75 & 9.04 \\
\hline Unidentified crustaceans & 9.63 & 20.95 & 72.41 & 63.18 & 33.33 & 24.40 & 43.75 & 54.91 \\
\hline Total & 9.63 & 20.95 & 72.41 & 43.61 & 33.33 & 24.40 & 43.75 & 38.12 \\
\hline
\end{tabular}

\section{DISCUSSION}

The present study provides the first detailed analysis of myctophid diets from the northern Scotia Sea and represents one of the most detailed studies undertaken in the Southern Ocean. However, it is important to recognise the spatial and temporal limitations of this study, which focused on a relatively small area NW of

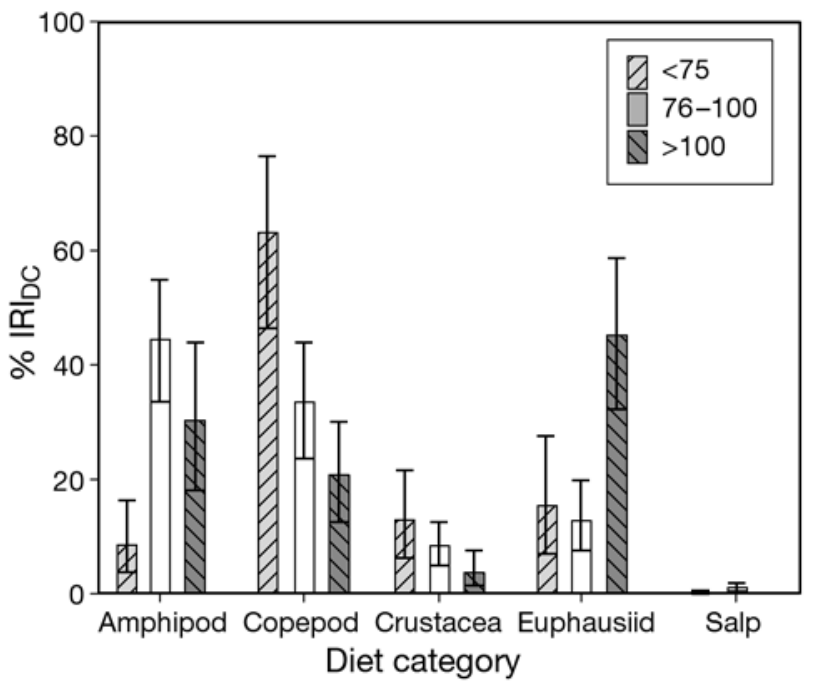

Fig. 6. Diet composition, expressed as percent index of relative importance by prey categories (\% IRI $\mathrm{DC}_{\mathrm{DC}}$ ) of all myctophid species grouped by size category (mm SL)
South Georgia during the austral autumn. Understanding the trophic role of myctophids in the Southern Ocean requires key data on spatial, temporal and ontogenetic variability in both diets and consumption rates.

In general, myctophids consume a range of larger mesozooplankton and smaller macrozooplankton species, particularly euphausiids, amphipods and calanoid copepods, which is consistent with studies carried out

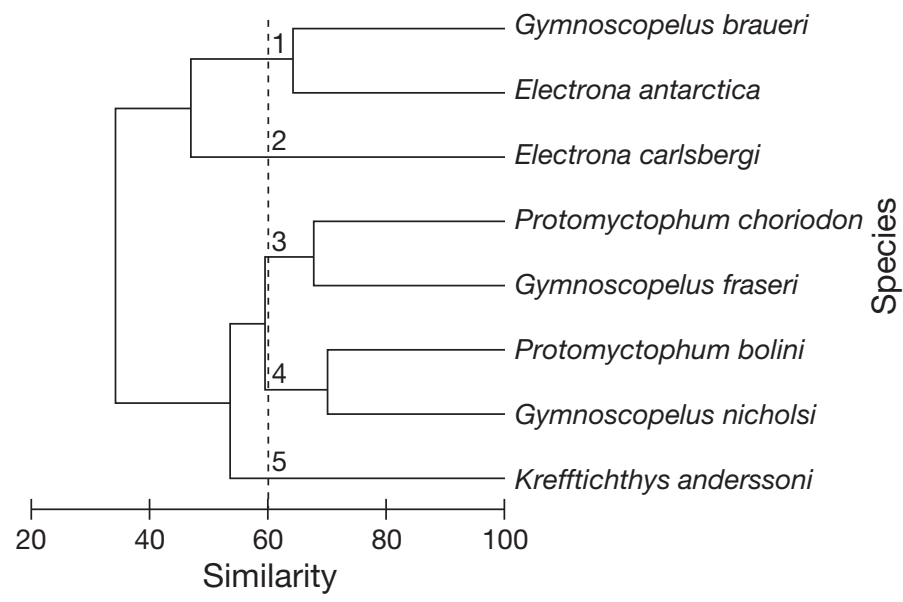

Fig. 7. Cluster diagram (group average) of Bray-Curtis similarity of the dietary composition (\% IRI data, excluding the category 'unidentified crustacea') of the 8 myctophid species with $n>20$ stomach content samples 


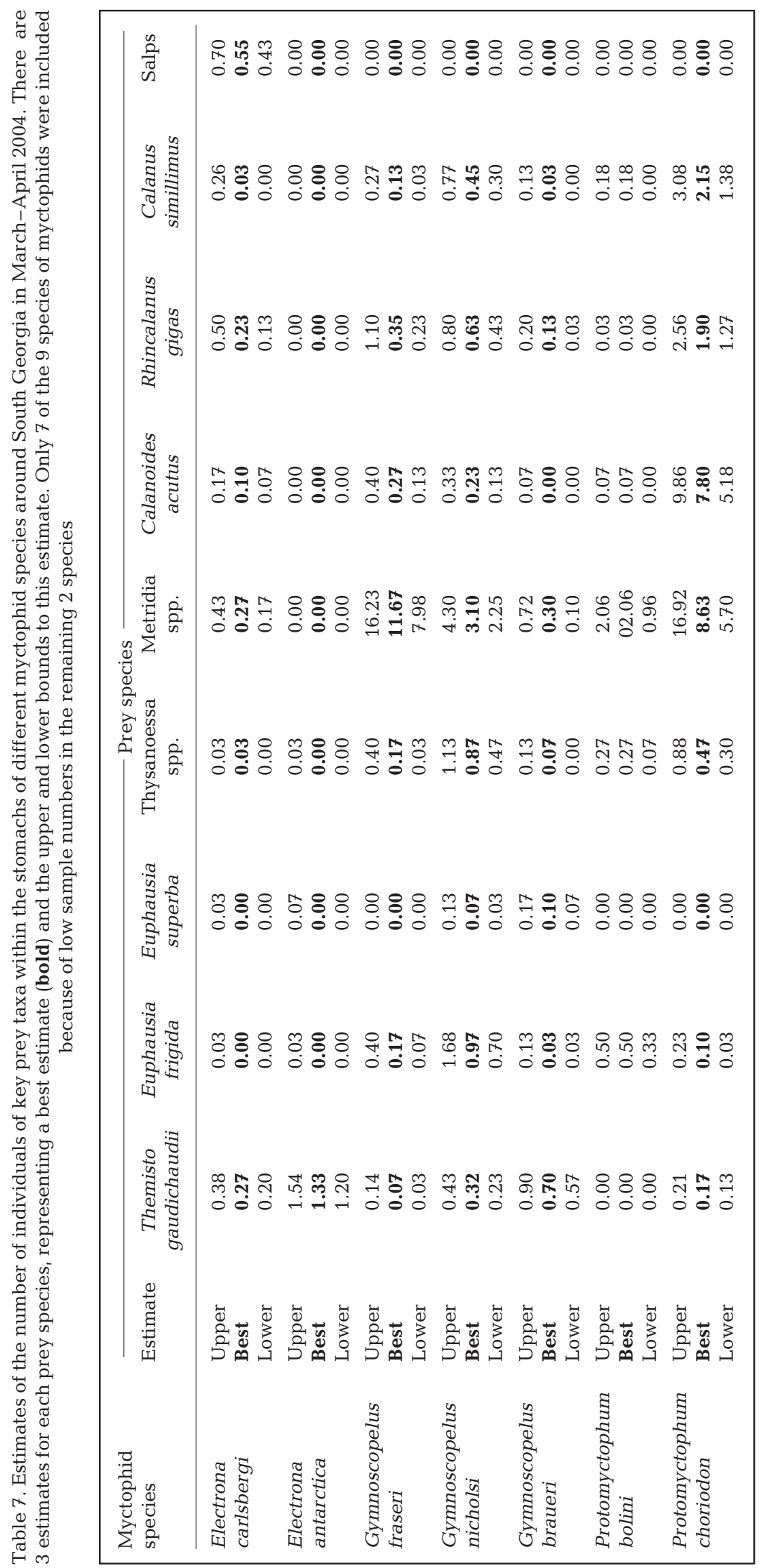

in other parts of the Southern Ocean (Rowedder 1979, Naumov et al. 1981, Kozlov \& Tarverdiyeva 1989, Gerasimova 1990, Pakhomov et al. 1996, Gaskett et al. 2001, Pusch et al. 2004) and on myctophid communities elsewhere (e.g. Young \& Blaber 1986, Hopkins \& Gartner 1992, Williams et al. 2001). It is, however, important to note that soft-bodied and easily digested prey, such as salps, may be underestimated in studies such as this.

Partitioning of resources is key to the coexistence of species that would otherwise be potential competitors (Schoener 1974), and such partitioning has been demonstrated in highly diverse low latitude myctophid assemblages (Hopkins \& Gartner 1992). In the present study, there was evidence of dietary segregation and specialisation (e.g. Electrona antarctica) that is linked, in part, to the vertical distribution and size of the fish predators (Collins et al. 2008a). It is difficult to disentangle active prey selection from simply feeding on the appropriate sized prey at a predator species' feeding depth. Nevertheless, there is clear niche separation between species, whatever the cause. Similarity analysis clearly demonstrated 2 clusters that were dominated by copepod consumers (Protomyctophum bolini, Protomyctophum choriodon, Gymnoscopelus fraseri and Gymnoscopelus nicholsi), and another dominated by consumers of the amphipod Themisto gaudichaudii (Electrona antarctica and Gymnoscopelus braueri). The size of the fish (predator) is a key determinant of diet, with larger prey, such as Antarctic krill, only being consumed by the largest myctophids. In addition, prey size (Fig. 8, also see Jennings et al. 2001), gape size of the fish (Karpouzi \& Stergiou 2003) and the filtering capability of the gill rakers probably influence diet selectivity. Similar dietary specialisation has been reported in other mesopelagic fish communities in the Southern Ocean (Gaskett et al. 2001), although the results differed somewhat to those of the present study, probably reflecting seasonal and regional differences in predator size and prey fields. Interestingly, the most abundant copepods in the area, which were the small 


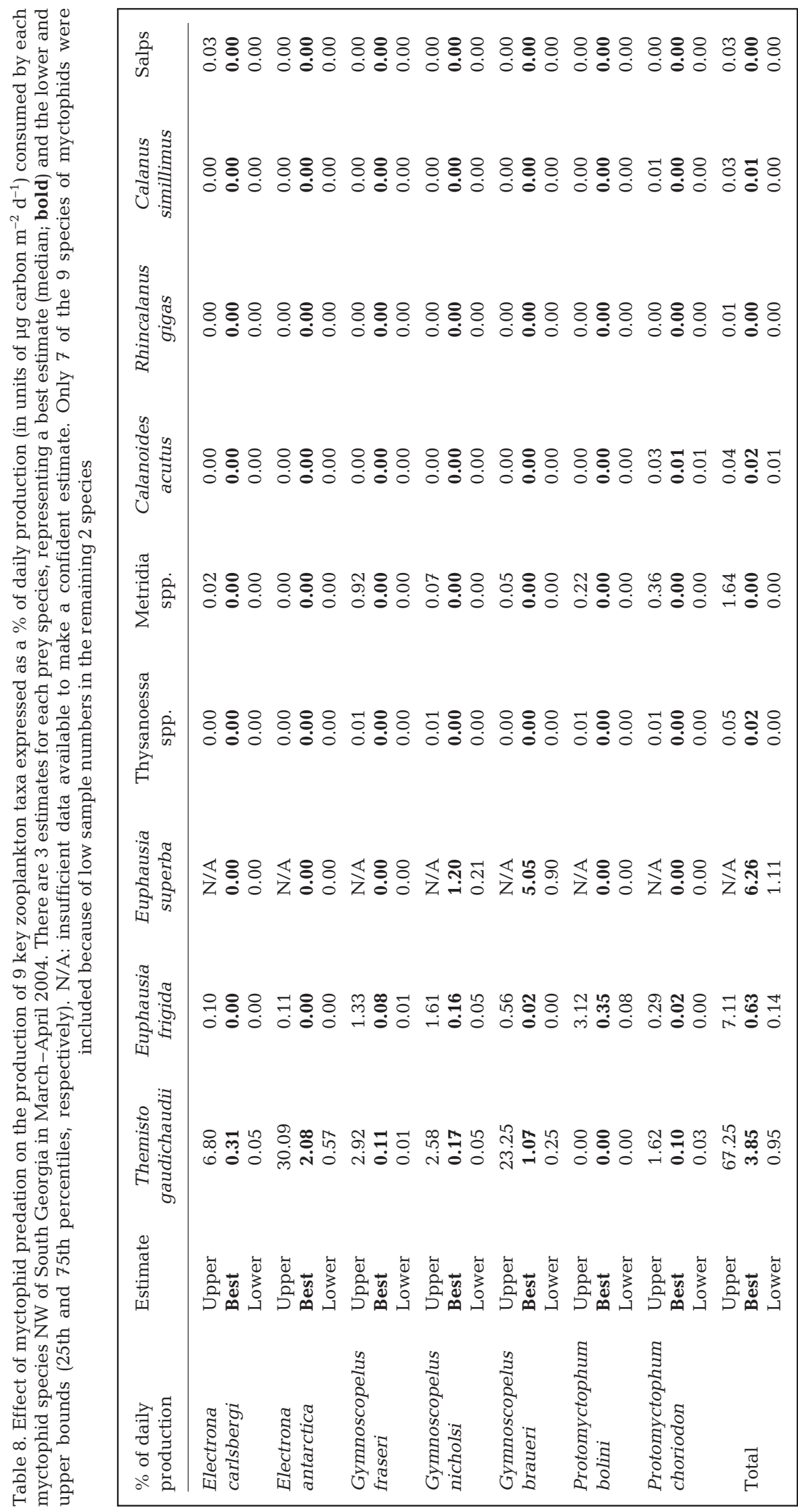

cyclopoid Oithona spp. and Oncaea spp. and the calanoid Ctenocalanus spp., were absent from myctophid stomachs. These species may either be too small for retention by gillrakers or too unprofitable to exploit.

The amphipod Themisto gaudichaudii was a key dietary item of 2 myctophid species, Gymnoscopelus braueri and Electrona antarctica, with E. antarctica feeding almost exclusively on $T$. gaudichaudii. Such dietary specialisation is somewhat surprising given the range of capture depth and size of E. antarctica examined here. In other parts of the Southern Ocean, the diet of E. antarctica is reported to be more diverse, being dominated by copepods in both the Lazarev Sea (Pakhomov et al. 1996) and near Macquarie Island (Gaskett et al. 2001) and dominated by euphausiids in the South Shetland Islands (Pusch et al. 2004). T. gaudichaudii clearly plays a key role in the northern Scotia Sea, where it is also an important prey of notothenid fish (Collins et al. 2008b, Main et al. 2009) and seabirds (Croxall et al. 1997), particularly in krill-poor years. It is also a key species on the Patagonian shelf and in other subAntarctic areas (Bocher et al. 2001).

There was some evidence of prey selection within the copepod portion of the diet. Copepod prey was dominated by older copepodite stages of Rhincalanus gigas and Metridia spp., particularly females. Older female polar copepods are generally more lipid rich than other stages (Hagen \& Schnack-Schiel 1996) and may be actively targeted by myctophids. Alternatively, the behaviour of these species may make them particularly susceptible to myctophid predation. Metridia spp. is a very active copepod that undergoes a diel vertical migration of around $200 \mathrm{~m}$ (Ward et al. 2006). R. gigas is relatively inactive and only reacts slowly to stimuli (Shreeve et al. 2002). Both behaviours, in different ways, may increase vulnerability to predation from an active fish predator. Hopkins \& Gart- 


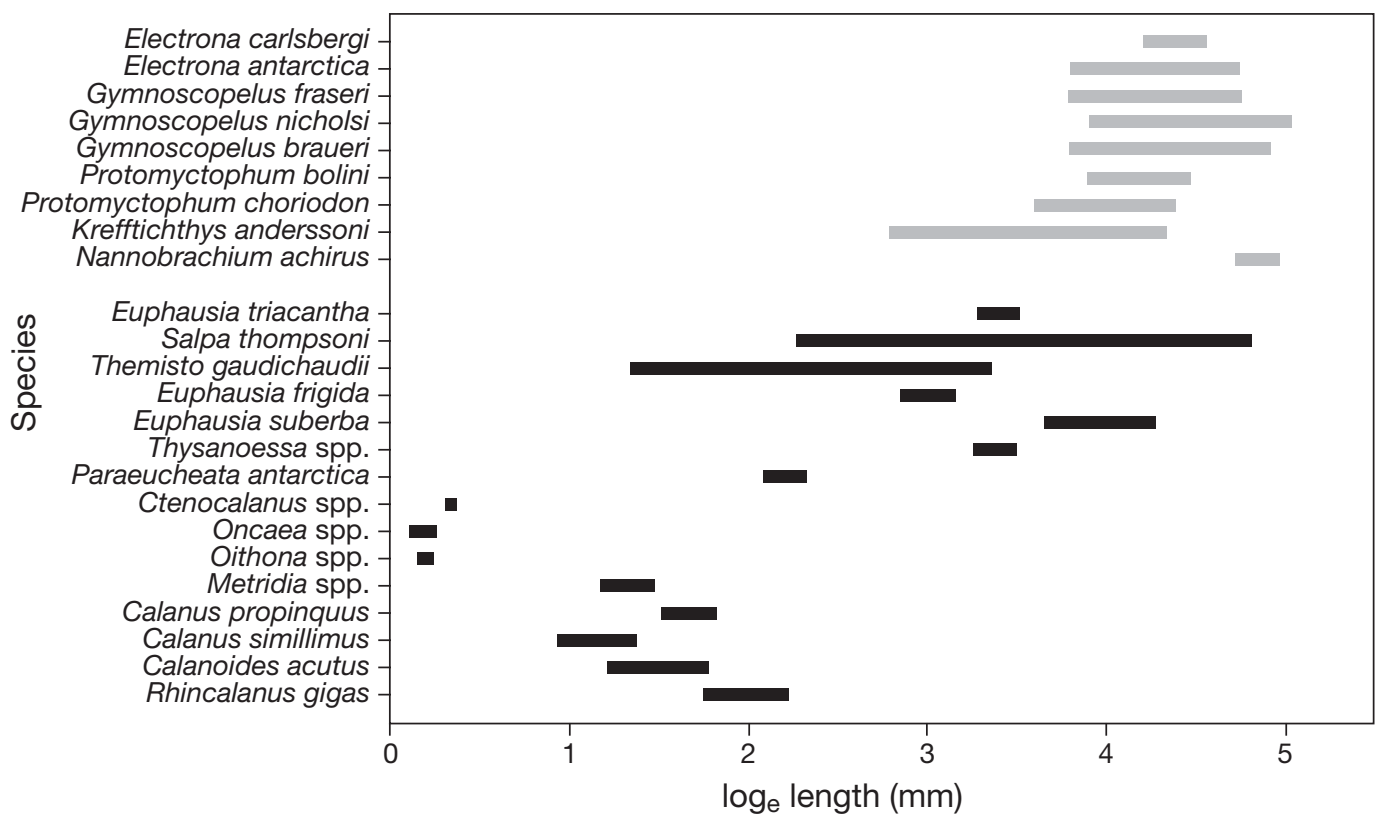

Fig. 8. Size range (natural log length, $\mathrm{mm}$ ) of myctophid predators (SL) and prey species (TL). Grey bars: predator sizes from the present study; black bars: prey species with sizes taken from Boltovskoy (1999) and Kirkwood (1984)

ner (1992) similarly found that myctophids preferentially consumed the intermediate to late growth stages of copepods in the Gulf of Mexico.

Adult Antarctic krill Euphausia superba are probably one of the largest prey species that can be handled by myctophids and, consequently, were only consumed by the larger myctophids (notably larger Gymnoscopelus braueri, G. nicholsi and Nannobrachium achirus). The significance of krill in the diet of Southern Ocean myctophids has been the source of debate in the literature (Williams 1985, Pakhomov et al. 1996, Pusch et al. 2004). The data presented here largely support the concept that myctophids provide an important krillindependent link between secondary production and higher predators (Murphy et al. 2007). However, it should be recognised that, while our study area (NW of South Georgia) is home to large populations of Antarctic krill, most of the krill in this area are large adults (Tarling et al. 2007), which are probably too large for most myctophids. It is possible that myctophids consume significant amounts of krill further south in the Scotia Sea, where krill are generally younger and smaller.

The presence of both Antarctic krill and Themisto gaudichaudii in the diet of Nannobrachium achirus was interesting, as this species was generally caught deeper than $600 \mathrm{~m}$ (Collins et al. 2008a) and krill and T. gaudichaudii are generally concentrated in the upper $400 \mathrm{~m}$. There is no evidence that $N$. achirus migrates to the surface to feed; however, during this study, krill were caught in RMT25 samples taken between 800 and $1000 \mathrm{~m}$, which supports the recent observations of krill actively feeding at abyssal depths in Marguerite Bay (Clarke \& Tyler 2008).

Two myctophid species, Protomyctophum bolini and Electrona carlsbergi, did not show any evidence of vertical migration (at least to the resolution of the sampling), and both consumed prey that was abundant in the 200 to $400 \mathrm{~m}$ depth zone which they occupied. In other species (e.g. Gymnoscopelus braueri and E. antarctica), there was some evidence of diel vertical migration (see Collins et al. 2008a), but likely net avoidance in the upper $400 \mathrm{~m}$ during daylight makes interpretation of day and night patterns difficult. Diel migrations are probably related to feeding and daylight avoidance of visual predators (Robison 2003). The dominance of the largely surface-dwelling Themisto gaudichaudii in the diet of $P$. bolini and E. carlsbergi suggests that they either feed near the surface at night or during the day, but are missed by daylight nets. Evidence from other studies supports the concept that diurnally vertically migrating myctophids predominantly feed at night, whilst those with weak or no migration show less distinct changes in stomach fullness (Williams et al. 2001).

One implication of the above behavioural pattern is that at least some species of myctophids are carrying prey below the pycnocline before carrying out the processes of digestion and egestion. This behaviour would contribute to the active flux of carbon from the mixed layers to the ocean interior (Longhurst et al. 1990). A number of studies have indicated that such active flux 
may be greater than first considered (Michaels et al. 1994, Tarling \& Johnson 2006) and that this process may explain some of the imbalances presently found in carbon export models (Smith 1992, Michaels et al. 1994). Tarling \& Johnson (2006) estimated that Antarc-

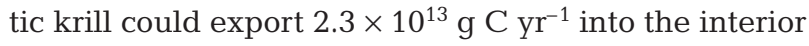
of the Southern Ocean through hunger/satiation vertical migrations. Given that krill biomass estimates (100 Mt; Atkinson et al. 2008) are roughly equivalent to those of myctophids in the Southern Ocean (70 to $200 \mathrm{Mt}$; Lubimova et al. 1987), it is possible that myctophids are contributing a similar order of active carbon flux in this ocean region.

Even though copepods were a major prey item of myctophids, myctophid predation had little impact on copepod productivity in this region. Macrozooplankton species were affected to a greater extent, particularly Themisto gaudichaudii and Euphausia superba. In the former instance, our best estimate was that 3.9\% of daily production (in terms of carbon) was consumed by myctophids, principally by Electrona antarctica and Gymnoscopelus braueri. For the latter, a best estimate of $6.3 \%$ of daily productivity was consumed by a combination of $G$. braueri and Gymnoscopelus nicholsi. However, some caution is warranted as to the overall impact of myctophid predation across wider ocean regions, given the patchy nature of macrozooplankton aggregations. Furthermore, these results must be placed in the wider context of seasonal and latitudinal changes in trophic relationships. Prey and predator sizes will change and there will sometimes be mismatches between prey availability and predator demand.

We found that the myctophid community in this region maintains a large dietary breadth, which is one way of minimising the impact of seasonal mismatches. In addition, there is good evidence of dietary segregation between species, related to inter-specific differences in body size and variations in migratory behaviour and depth selection. These differences potentially minimise competition and the exhaustion of any one particular food resource. There is likely to be a considerable flux of biomass through the myctophid community, which is largely independent of Antarctic krill. Together, these findings reveal the myctophid community to be a robust component of the mesopelagic system, capable of exploiting a wide range of food sources and of acting as a major link between lower and higher trophic levels in this region.

Acknowledgements. The authors thank Captain J. Burgan and the scientists and crew on board RRS 'James Clark Ross' during Cruise 100, and P. Rothery for statistical advice. The manuscript benefitted from the detailed and extremely helpful comments of 4 anonymous reviewers. This is a contribution to the Discovery 2010 Programme at BAS.

\section{LITERATURE CITED}

Andersen NG (1999) The effects of predator size, temperature, and prey characteristics on gastric evacuation in whiting. J Fish Biol 54:287-301

Andersen NG, Beyer JE (2008) Precision of ingestion time and evacuation predictors for individual prey in stomachs of predatory fishes. Fish Res 92:11-22

Atkinson A, Whitehouse MJ, Priddle J, Cripps GC, Ward P, Brandon MA (2001) South Georgia, Antarctica: a productive, cold water, pelagic ecosystem. Mar Ecol Prog Ser 216: 279-308

Atkinson A, Siegel V, Pakhomov E, Rothery P (2004) Longterm decline in krill stocks and increase in salps within the Southern Ocean. Nature 432:100-103

- Atkinson A, Siegel V, Pakhomov EA, Rothery P and others (2008) Oceanic circumpolar habitats of Antarctic krill. Mar Ecol Prog Ser 362:1-23

Bocher P, Cherel Y, Labat JP, Mayzaud P, Razouls S, Jouventin P (2001) Amphipod-based food web: Themisto gaudichaudii caught in nets and by seabirds in Kerguelen waters, southern Indian Ocean. Mar Ecol Prog Ser 223: 261-276

Boltovskoy D (1999) South Atlantic zooplankton. Backhuys Publishers, Leiden

Cherel Y, Putz K, Hobson KA (2002) Summer diet of king penguins (Aptenodytes patagonicus) at the Falkland Islands, southern Atlantic Ocean. Polar Biol 25:898-906

> Cherel Y, Ducatez S, Fontaine C, Richard P, Guinet C (2008) Stable isotopes reveal the trophic position and mesopelagic fish diet of female southern elephant seals breeding on the Kerguelen Islands. Mar Ecol Prog Ser 370:239-247

Clarke KR, Gorley RN (2006) PRIMER v6: User manual/tutorial. PRIMER-E, Plymouth

Clarke A, Tyler PA (2008) Adult Antarctic krill feeding at abyssal depths. Curr Biol 18:282-285

Clarke KR, Warwick RM (2001) Changes in marine communities: An approach to statistical analysis and interpretation. PRIMER-E, Plymouth

Collins MA, Xavier JC, Johnston NM, North AW and others (2008a) Patterns in the distribution of myctophid fish in the northern Scotia Sea ecosystem. Polar Biol 31:837-851

Collins MA, Shreeve RS, Fielding S, Thurston MH (2008b) Distribution, growth, diet and foraging behaviour of the yellow-fin notothen Patagonotothen guntheri on the Shag Rocks shelf (Southern Ocean). J Fish Biol 72:271-286

Cortes E (1997) A critical review of methods of studying fish feeding based on analysis of stomach contents: application to elasmobranch fishes. Can J Fish Aquat Sci 54:726-738

Croxall JP, Prince PA, Reid K (1997) Dietary segregation of krill-eating south Georgia seabirds. J Zool (Lond) 242: 531-556

Gaskett AC, Bulman C, He X, Goldsworthy SD (2001) Diet composition and guild structure of mesopelagic and bathypelagic fishes near Macquarie Island, Australia. NZ J Mar Freshw Res 35:469-476

Gerasimova OV (1990) Feeding and food intake of Electrona carlsbergi (Taning, 1932) Myctophidae. CCAMLR Sel Sci Pap 7:411-416

Gjøsaeter J, Kawaguchi K (1980) A review of the world resources of mesopelagic fish. Food and Agriculture Organization of the United Nations, FAO Fisheries Technical Paper No. 193, Rome

> Guinet C, Dubroca L, Lea MA, Goldsworthy S and others (2001) Spatial distribution of foraging in female Antarctic fur seals Arctocephalus gazella in relation to oceanographic variables: a scale-dependent approach using geo- 
graphic information systems. Mar Ecol Prog Ser 219: 251-264

Hagen W, Schnack-Schiel SB (1996) Seasonal lipid dynamics in dominant Antarctic copepods: energy for overwintering or reproduction? Deep-Sea Res I 43:139-158

Hansson S (1998) Methods of studying fish feeding: a comment. Can J Fish Aquat Sci 55:2706-2707

Hempel G (1985) On the biology of the polar seas especially the Southern Ocean. In: Gray JS, Christiansen ME (eds) Marine biology of polar regions and effects of stress on marine organisms. John Wiley, Chichester, p 3-34

Hirst AG, Roff JC, Lampitt RS (2003) A synthesis of growth rates in marine epilagic invertebrate zooplankton. Adv Mar Biol 44:1-142

Hopkins TL, Gartner JV (1992) Resource-partitioning and predation impact of a low-latitude myctophid community. Mar Biol 114:185-197

Hulley PA (1981) Results of the research cruises of FRV 'Walther Herwig' to South America. 58. Family Myctophidae (Osteichthyes, Myctophiformes). Arch FischWiss 31(Suppl 1):1-303

Hulley PA (1990) Myctophidae. In: Gon O, Heemstra PC (eds) Fishes of the Southern Ocean. J.L.B. Smith Institute of Ichthyology, Grahamstown, p 146-178

Jennings S, Pinnegar JK, Polunin NVC, Boon TW (2001) Weak cross-species relationships between body size and trophic level belie powerful size-based trophic structuring in fish communities. J Anim Ecol 70:934-944

Karpouzi VS, Stergiou KI (2003) The relationships between mouth size and shape and body length for 18 species of marine fishes and their trophic implications. J Fish Biol 62: 1353-1365

Kirkwood JA (1984) A guide to the Euphausiacea of the Southern Ocean. ANARE Res Notes 1:1-45

Kozlov AN, Tarverdiyeva MI (1989) Feeding of different species of Myctophidae in different parts of the Southern Ocean. J Ichthyol 29:160-167

Longhurst LR, Bedo AW, Harrison WG, Heaf EJH, Sameoto DD (1990) Vertical flux of respiratory carbon by oceanic diel migrant biota. Deep-Sea Res 37:685-694

Lubimova TG, Shust KV, Popkov VV (1987) Specific features in the ecology of Southern Ocean mesopelagic fish of the family Myctophidae Biological resources of the Arctic and Antarctic (collected papers). Nauka Press, Moscow, p 320-337 (in Russian)

Main CE, Collins MA, Mitchell R, Belchier M (2009) Identifying patterns in diet of mackerel icefish (Champsocephalus gunnari) at South Georgia using bootstrapped confidence intervals of a dietary index. Polar Biol 32:569-581

Mann KH (1984) Fish production in open ocean ecosystems. In: Fasham MJR (ed) Flows of energy and materials in marine ecosystems. Plenum Press, New York, p 435-458

Michaels AF, Bates NR, Buesseler KO, Carlson CA, Knap AH (1994) Carbon-cycle imbalances in the Sargasso Sea. Nature 372:537-540

Murphy EJ, Watkins JL, Trathan PN, Reid K and others (2007) Spatial and temporal operation of the Scotia Sea ecosystem: a review of large-scale links in a krill centred food web. Philos Trans R Soc Lond B Biol Sci 362:113-148

Naumov AG, Svetlov MF, Kozlov AN, Pinskaya IA (1981) Some features of the distribution and feeding of Electrona

Editorial responsibility: Yves Cherel,

Villers-en-Bois, France carlsbergi (Taning) (Myctophidae) in the Scotia Sea. J Ichthyol 21:467-472

Olsson O, North AW (1997) Diet of the king penguin Aptenodytes patagonicus during 3 summers at South Georgia. Ibis 139:504-512

Pakhomov E, Perissinotto R, McQuaid CD (1996) Prey composition and daily rations of myctophid fishes in the Southern Ocean. Mar Ecol Prog Ser 134:1-14

Pusch C, Hulley PA, Kock KH (2004) Community structure and feeding ecology of mesopelagic fishes in the slope waters of King George Island (South Shetland Islands, Antarctica). Deep-Sea Res I 51:1685-1708

Reid K, Davis D, Staniland IJ (2006) Spatial and temporal variability in the fish diet of Antarctic fur seal in the Atlantic Sector of the Southern Ocean. Can J Zool 84:1025-1037

$>$ Robison BH (2003) What drives the diel vertical migrations of antarctic midwater fish? J Mar Biol Assoc UK 83:639-642

> Rodhouse PG, White MG, Jones MRR (1992) Trophic relations of the cephalopod Martialia hyadesi (Teuthoidea, Ommastrephidae) at the Antarctic Polar Front, Scotia Sea. Mar Biol 114:415-421

Ross ST (1986) Resource partitioning in fish assemblages: a review of field studies. Copeia 1986:352-388

Rowedder U (1979) Feeding ecology of the myctophid Electrona antarctica (Gunther, 1878) (Teleostei). Meeresforschung 27:252-263

Schoener TW (1974) Resource partitioning in ecological communities. Sci Total Environ 185:27-39

Shreeve RS, Ward P, Whitehouse MJ (2002) Copepod growth and development around South Georgia: relationships with temperature, food and krill. Mar Ecol Prog Ser 233: 169-183

Smith KLJ (1992) Benthic boundary layer communities and carbon cycling at abyssal depths in the central North Pacific. Limnol Oceanogr 37:1034-1056

Tarling GA, Johnson ML (2006) Satiation gives krill that sinking feeling. Curr Biol 16:R83-R84

Tarling GA, Cuzin-Roudy J, Thorpe S, Shreeve R, Ward P, Murphy EJ (2007) Recruitment of Antarctic krill Euphausia superba in the South Georgia region: adult fecundity and the fate of larvae. Mar Ecol Prog Ser 331:161-179

Tsarin SA (1997) Myctophids of the sound scattering layer and their place in pelagic food webs. 14th Lowell Wakefield Fisheries Symposium on Forage Fishes in Marine Ecosystems, Anchorage, AK. Forage fishes in marine ecosystems: University of Alaska Sea Grant, AK-SG-97-01, Fairbanks, AK, p 271-275

- Ward P, Shreeve RS, Tarling G (2006) The autumn mesopelagic community at South Georgia: biomass, population structure and vertical distribution. Polar Biol 29:950-962

Williams R (1985) Trophic relationships between pelagic fish and euphausids in Antarctic waters. In: Siegfried WR, Condy PR, Laws RM (eds) Antarctic nutrient cycles and food webs. Springer-Verlag, Berlin, p 452-459

Williams A, Koslow JA, Terauds A, Haskard K (2001) Feeding ecology of five fishes from the mid-slope micronekton community off southern Tasmania, Australia. Mar Biol 139:1177-1192

> Young JW, Blaber SJM (1986) Feeding ecology of three species of midwater fishes associated with the continental slope of eastern Tasmania. Mar Biol 93:147-156

Submitted: December 3, 2008; Accepted: April 16, 2009

Proofs received from author(s): June 18, 2009 